\title{
Research Paper \\ Representation of Farmers' Professional Identities in Shushtar District, Iran: A Study Based on Q-Methodology
}

\author{
Gholamreza Merdasi ${ }^{1}$, *Masoud Yazdanpanah², Masoud Baradaran ${ }^{3}$, Masoumeh Forouzani
}

1. MSc., Department of Agriculture Extension and Education, Faculty of Agriculture Engineering and Rural Development, Ramin Agriculture and Natural Resources University, Khuzestan, Iran.

2. Assistant Professor, Department of Agriculture Extension and Education, Faculty of Agriculture Engineering and Rural Development, Ramin Agriculture and Natural Resources University, Khuzestan, Iran.

3. Associate Professor, Department of Agriculture Extension and Education, Faculty of Agriculture Engineering and Rural Development, Ramin Agriculture and Natural Resources University, Khuzestan, Iran.

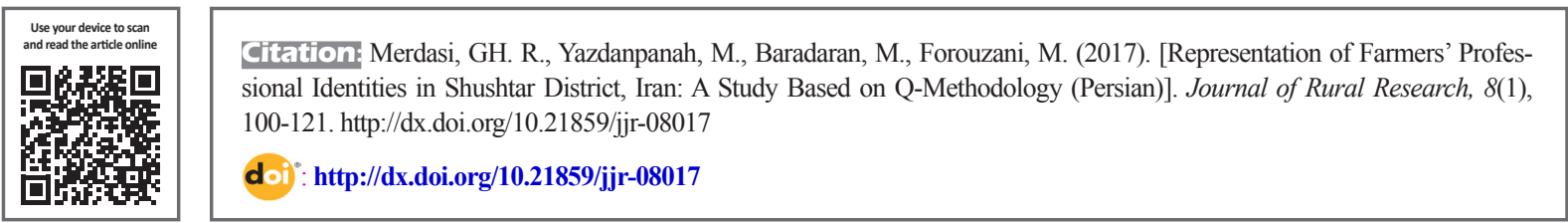

Received: 02 Jun. 2016 Accepted: 09 Aug. 2016

Keywords:

Identity, Farmers, Q methodology,

Khuzestan

\begin{abstract}
A B STRACT
New policies for agricultural transition can only be effective if the policy is understood and adopted at the farm level. In countries such as Iran cultural factors embodied in identity can provide major obstacles to change because traditional and religious beliefs are important in everyday decision-making. Consequently the need to understand identity as a key factor is important in an Iranian context. Selfbeliefs about being a particular type of person, the roles that such a person should play and commitment to that particular identity play an important role in determining farmers' behavioral choice - particularly when 'new' behaviours challenge existing beliefs about "good farming" as in the case of regime change. Understanding these 'identities' and the roles associated with them can help us both address the issue of heterogeneity within the farming communities and identify which behaviours are culturally important and therefore may require specific consideration in policy formulation to promote transition. To address this, the aim of this study is to employ q-methodology as a means of generating a typology of farmers with specific identities. This study will be based on existing data gathered in a study of farmers in Khuzestan province, in southern Iran. Based on the review of the agricultural literature, interviews with farmers and interviews with agricultural specialists, the study constructed a concourse with 120 statements. Then, based on ranking by experts, we selected 43 q-samples from this expert ranking. Fifty farmers were selected through purposeful sampling (good farmers introduced by local agricultural officers) as a P-set, completed the Q-sort procedure. Data analysis identified a number of heterogeneous farmer groups based on their identity.
\end{abstract}

\section{Extended Abstract}

\section{Introduction}

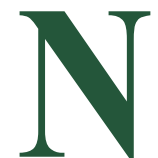

ew policies for agricultural transition can be only effective if the policy is understood and adopted at the farm level.
In countries such as Iran cultural factors embodied in identity can provide major obstacles to change because traditional and religious beliefs are important in everyday decision-making. Consequently, the need to understand identity as a key factor is important in an Iranian context. Self-beliefs about being a particular type of person, the roles that such a person should play, and commitment to

\section{* Corresponding Author:}

Masoud Yazdanpanah, PhD

Address: Department of Agriculture Extension and Education, Faculty of Agriculture Engineering and Rural Development, Ramin Agriculture and Natural Resources University, Khuzestan, Iran.

Tel: +98 (61) 36524348

E-mail: masoudyazdan@gmail.com 
that particular identity play important roles to determine farmers' behavioral choice; particularly when 'new' behaviors challenge the existing beliefs about "good farming" as in the case of regime change. To understand the influence of self-identity due to changing agricultural policy is a new approach proposed by Burton and Wilson based on the "identity theory" proposed by the social psychologist Sheldon Stryker (Stryker \& Burke, 2000).

Based on Stryker theory, the self is a set of socially constructed roles reflecting the extent to which a person sees himself or herself fulfilling the criteria for a particular societal role (Pelling \& White, 2009). This social role emerges from social experience (Mead, 1934; cited in Burton, 2004) and the people's responses to both formal and informal expectations (Stenholm \& Hytti, 2014). Self-identity, therefore, is generally interpreted as a label that people use to describe themselves, as well as something that is expected to have an important influence on the behavior (Cook, Kerr, \& Moore, 2002). It legitimizes the individuals' behaviors in society (Stenholm \& Hytti, 2014) or adjusts the self with the rules of the game. However, identity is the theoretically broader construct, encompassing many other aspects of the self, such as self-image, and social roles (Stryker, 1980). Therefore, it is a complex concept used in different ways in diverse theoretical discourses (Vesala \& Vesala, 2010) and can encompass all aspects of the self such as physical attributes, preferences, values, personal goals, habitual behavior, personality traits, and personal narratives.

When experience is internalized, the person' Identity is established and the individual accepts this experience as her/his own (Stryker, 1980). Stryker proposed various components of self for each role occupied in life. As such people have multiple identities, the identities were fluid and context dependent (Stenholm \& Hytti, 2014). Stryker argued that such multiple identities were managed through "hierarchy of salience". Stryker argued that self is influenced by the wider social structure, and in turn is an active creator of social behavior. Central to identity theory is that to understand action — or in more psychological terms, to understand and predict behavior - the self and a wider social structure as being inextricably linked must be conceived.

Understanding such 'identities' and the roles associated with them can help to address the issue of heterogeneity within the farming communities and identify which behaviors are culturally important and, hence, may require specific consideration in policy formulation to promote transition.
To the authors best knowledge, no studies are conducted regarding farmers' identity. Therefore, the current study aimed at using Q-methodology to establish the perceptual frameworks of farmers for their perception about themselves and their activities in more details. In particular, it is concerned with outlining how farmers perceive themselves and their related value in their farming practice. These normative aspects are particularly relevant in the context of new policies aimed at encouraging farmers to adopt the best farming practices. This aspect is very important, as it is very hard to judge if such policies are socially acceptable and therefore capable of being implemented, until it is known what "discourses" farmers are using about themselves. Indeed, finding out how people understand an issue is essential to the whole process of "problem identification," both normatively and politically.

\section{Methodology}

To address this issue, the current study aimed at employing Q-methodology as a means of generating a typology of farmers with specific identities. The current study was based on the existing data gathered in a study of farmers in Khuzestan province, Southern Iran. Based on the review of the agricultural literature, interviews with farmers and interviews with agricultural specialists, the study constructed a concourse with 120 statements. Then, based on ranking the statements by the experts, 43 Q-samples were selected. Fifty farmers were selected through purposeful sampling (good farmers introduced by local agricultural officers) as a P-set, and completed the Q-sort procedure.

\section{Results}

Factor analysis of Q sorts revealed three major discourses among the 50 farmers: 1 ) who believed both production and safty2) who believed both production and traditional aspect 3) traditional farmers. Three farmers did not load on any factors and is not represented by these major viewpoints. The number of farmers (Q sorts) loading significantly on each factor, and level of variance explained by each factor, are 19\%, 22\% and $20 \%$ respectively. These factors represent a difference among farmers' identity.

\section{Discussion}

Current literature confirm that farmers have different identity that can influence their perception and finally their behaviour. Our result revealed that this assumption confirm between Iranian farmers too. This paper has found that this diversity can be grouped into three identities. Although these identities were analyzed for their contrasting features, they also have common character- 
istics. There are similarities and also precise differences among them. As such, each identity produces an exactly different description of agriculture as whole and is linked with a distinctive set of rationalization for doing a given behaviour. Policy makers in their planning and policy in agriculture domain should consider these identities.

\section{Conclusion}

Data analysis identified a number of heterogeneous farmer groups based on their identity.

\section{Acknowledgments}

This research did not receive any specific grant from funding agencies in the public, commercial, or not-forprofit sectors.

\section{Conflict of Interest}

The authors declared no conflicts of interest. 


\title{
بازنمايى هويتهاى حرفهاى كشاورزان شهرستان شوشتر: بثرهشى بر بايه روششناسى كيو
}

\author{
غلامرضا مرداسى'، "مسعود يزدانيناه'، مسعود برادران"، معصومه فروزانى'
}

ا- كارشناس ارشد، كروه ترويج و آموزش كشاورزى، دانشكده مهندسى زراعى و عمران روستايى، دانشعاه كثاورزى و منابع طبيعى رامين خوزستان، خوزستان، ايران.

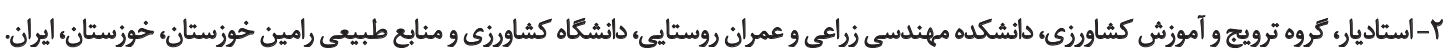

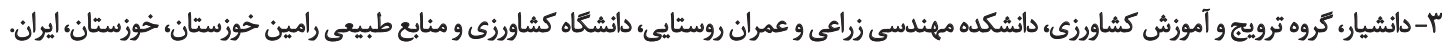

\section{حكبد}

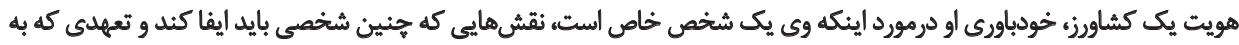

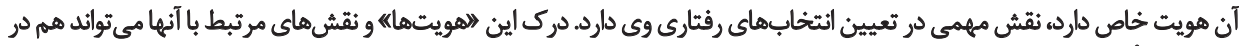

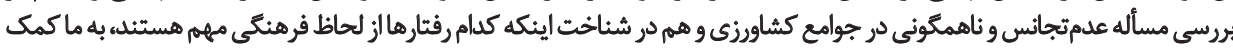

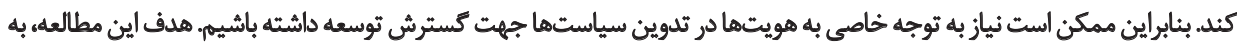

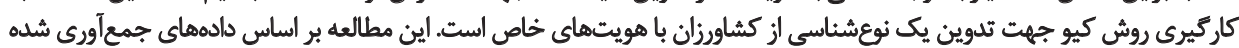

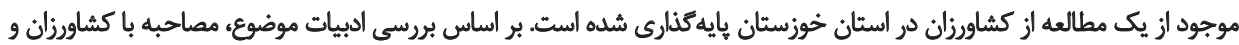

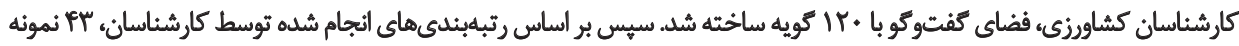

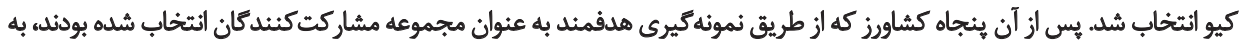

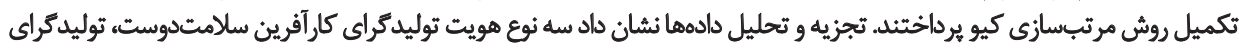
سنتى و سئتى در ميان كشاورنان وجود بردي دارد.

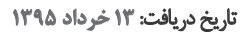

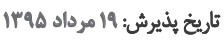

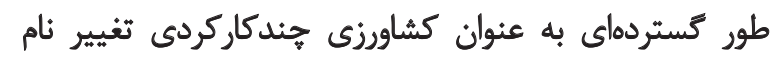

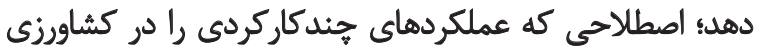

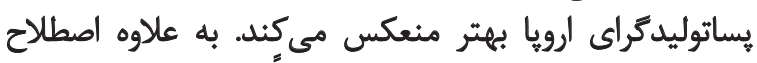

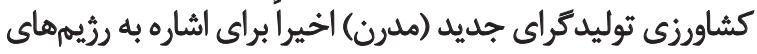

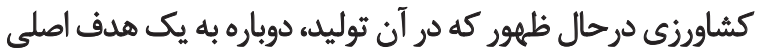

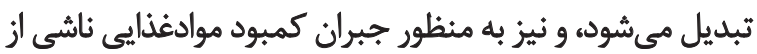

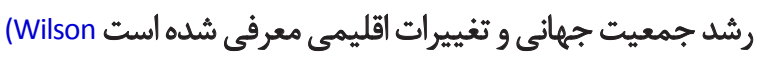

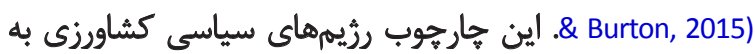

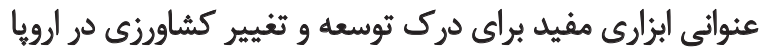

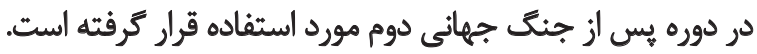

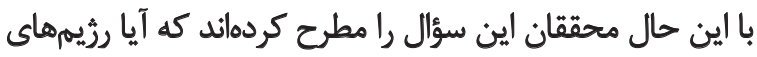

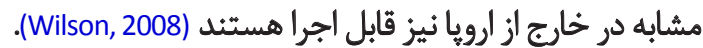

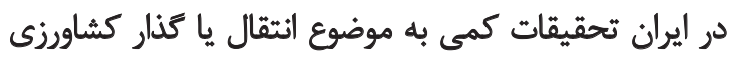

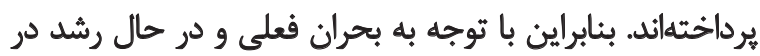

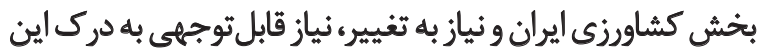

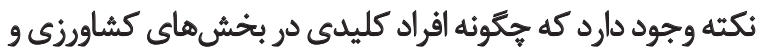

dole

اخيراً محققان كشاورزى و روستايي در اتحاديه ارويا و ديكر بتري

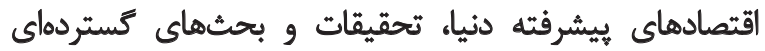

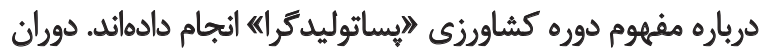

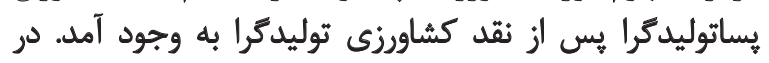

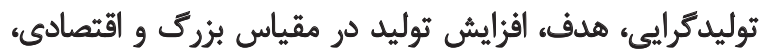

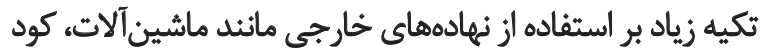

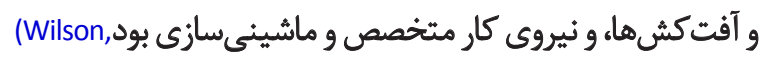

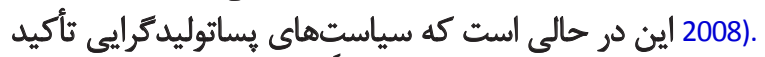

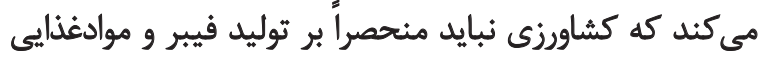

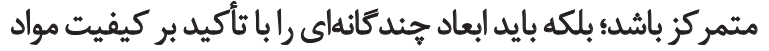

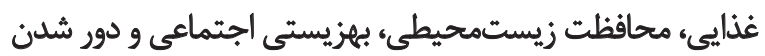

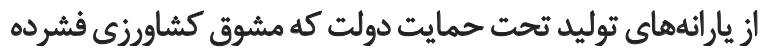

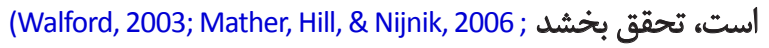
بحث هاى انثقادى درمورد اصطلاح يساتوليدكرايى : Willson, 2008) كمك كرد كشاورزى بپاتوليدكرا به به (Mather et al., 2006,)

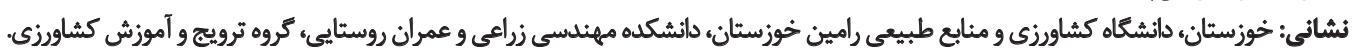
" masoudyazdan@gmail.com بيست الكترونيكي: تلفني 


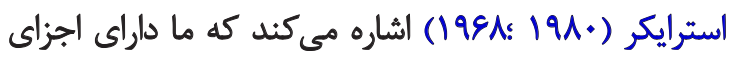

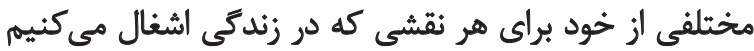

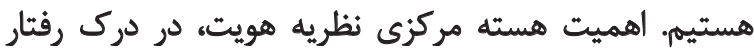

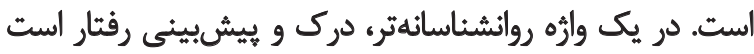

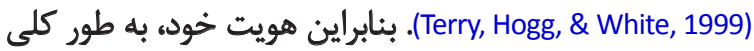

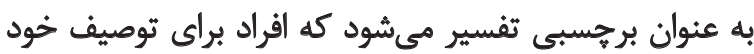

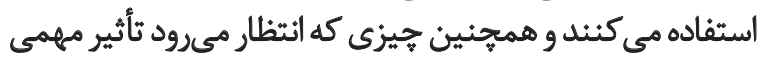
بر نيت رفتارى افراد داشته باشد (Cook et al., 2002). استرايكر

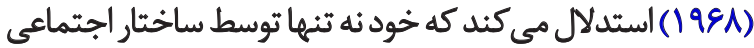

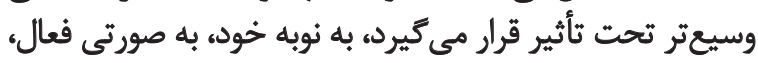
ايجادكنثده رفتار هاي اجتماعى است.

هويت از طريق فرايندهاى خودطبقهابندى و يا تعيين تصور از

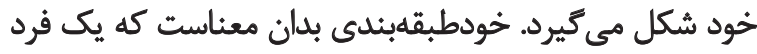

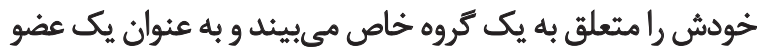

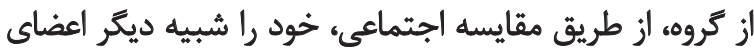

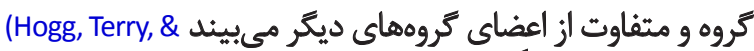

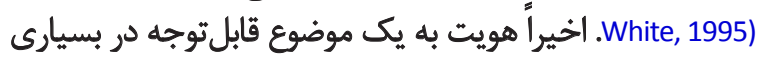

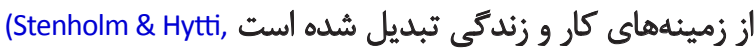

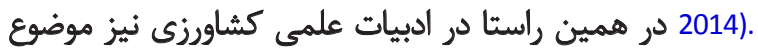

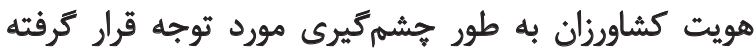

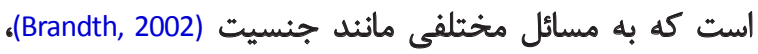
حرفهاى كرى (Gonzales \& Benito, 2001)، مشاركت در مر عمل

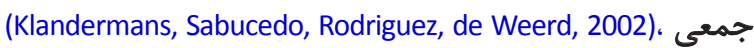

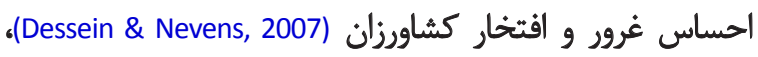

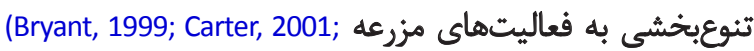
Mikko Vesala, Peura, \& McElwee, 2007; Sharpley \& Vass, 2006) وطرحهاى كشاورزى-زيستمحيطى (Lockie, 2006) يرداختهاند. بعضى از اين تحقيقات به صورت خاص به بروسى هويت

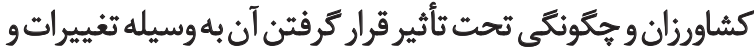

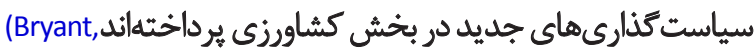
1999; Dessein \& Nevens, 2007; Gonzales \& Benito, 2001; Mikko Vesala et al., 2007; Vesala \& Vesala, 2010; McElwee, 2008; Burw (ton, 2004; McGuire, Morton, \& Cast, 2012)

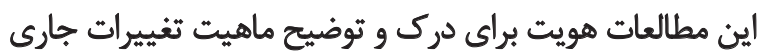

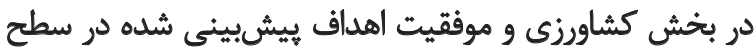

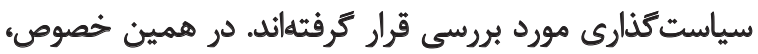

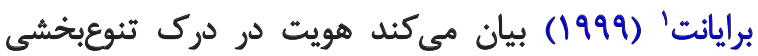

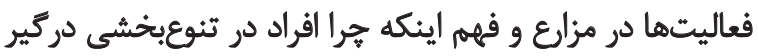

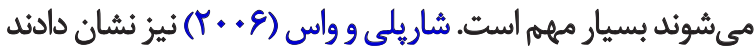

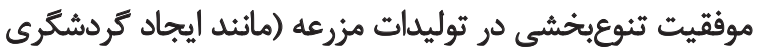

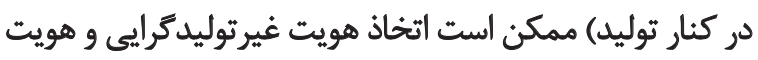

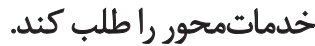

1. Brayant
سياسى، تغييرات فعلى و نياز به تغيير را هار هوبوبندى مي كنيند.

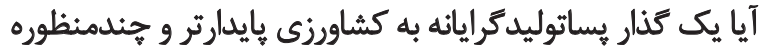
در حال وقوع است؟ و يا تأكيد بسيارى بر توليد برائى بازازارمحور و فناورانه وجود دارد؟

تدوين سياست براى كذار كشاورزى تنها درصورتى مي تواند

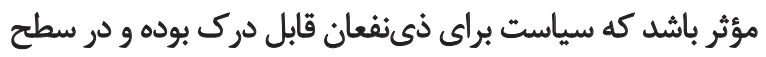

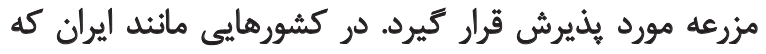

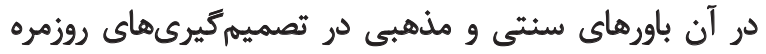

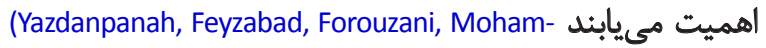

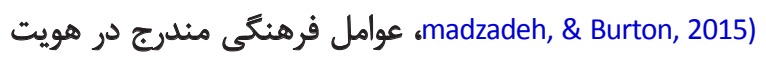

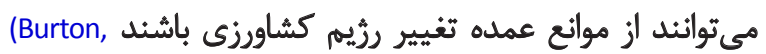
( Kuczera, \& Schwarz, 2008)

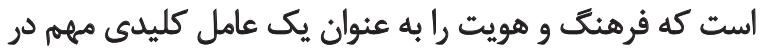

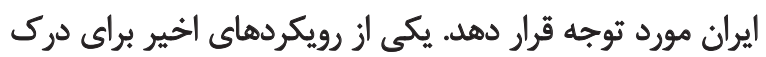
تأثير هويت توسط برتون و وئر ويلسون (Burton \& Wilson, 2006) و بر اساس الإظريه هويته، ارائه شده توسط روائ توانشناس اجتماعى

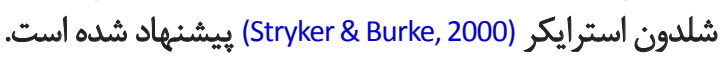

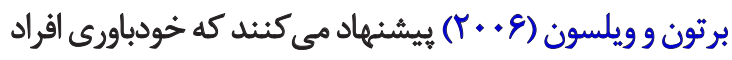

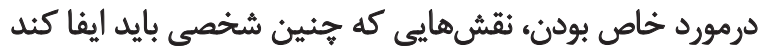

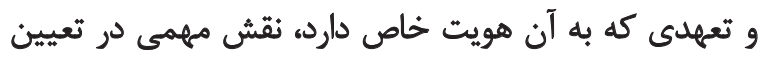

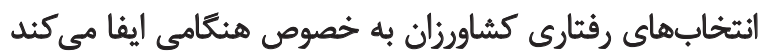

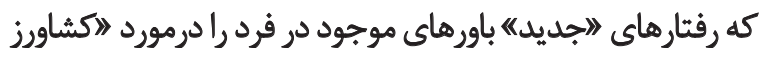

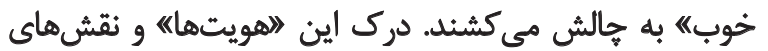

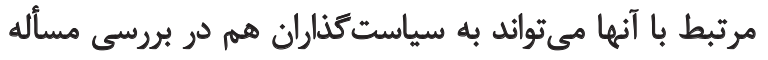

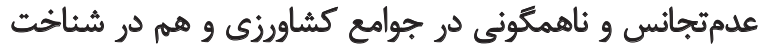

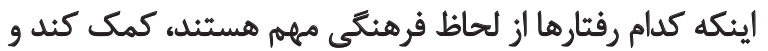

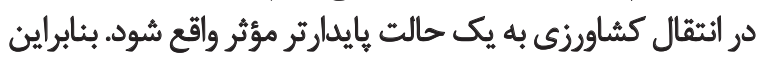

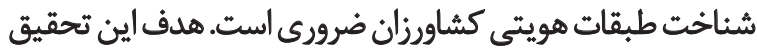
شناخت هويت كشاورزان است.

\section{مرورى بر ادبيات موضوع}

هويت، بخشى از خودينداره است و به عنوان ياسخى به سؤال

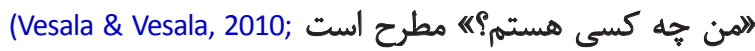
كماجنين به معنى لقب يا اصطلاحى :Stenholm \& Hytti, 2014) براى توصيف خود است (Cook, Kerr, \& Moore, 2002) . مفهوم هويت فردى از نظريه هويت استرايكر كرفته شده است Stryker)

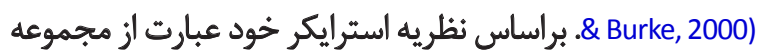

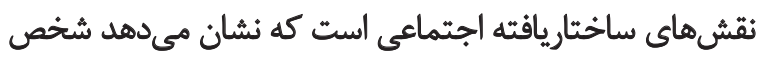

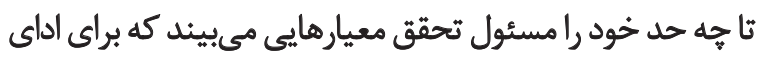
يك نقش اجتماعى خاص لازم است (Pelling \& White, 2009).

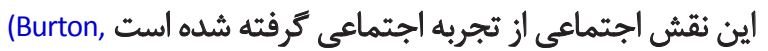

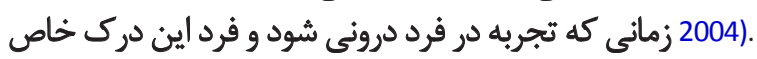
جهان را از خودش بيذيرد، هويت ايجاد مي شودود (Stryker, 1980). 
ارويا تحقيقات كستردهاي در اين زمينه انجام كرفته است. نتايج مطالعات قبلى در زمينه هويت تا حدودى متناقض|ندي

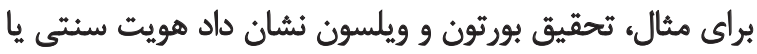

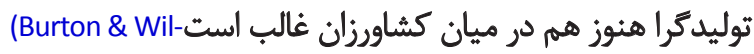

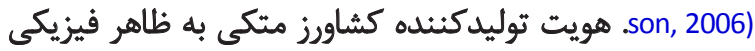

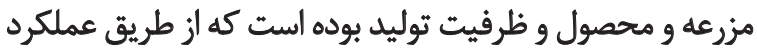

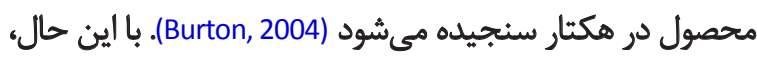

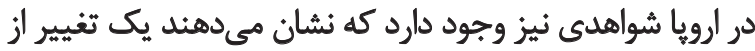

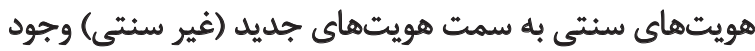

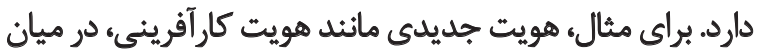

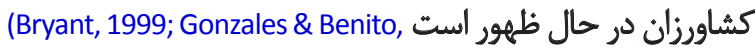
2001; Carter, 2001; Vesala \& Rantanen, 1999; Podedworna, .1998; Yakova, 2006; Laoire, 2002) به كفته برايانت (1999) كشاورزان كارآفرين به دنبال كسب

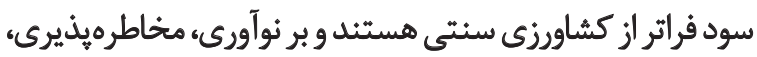
تنوع و كوناتونى مزرعه تأكيد مي كنيند (Stenholm \& Hytti, 2014).

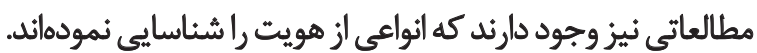

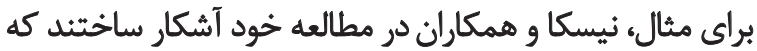

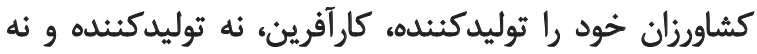

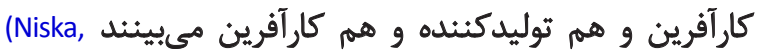

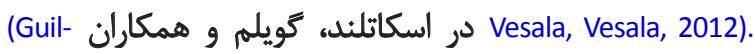

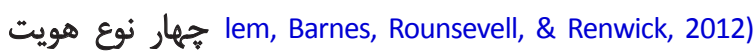

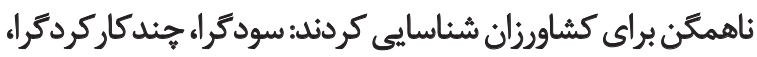

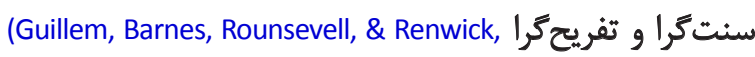

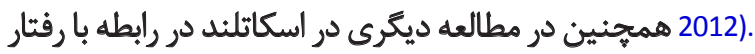

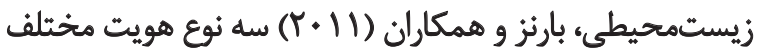

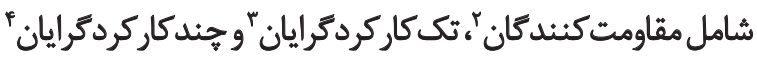
تشخيص دادئد (Barnes, Willock, Toma, \& Hall, 2011).

جيمز و هندريكسن سه نوع هويت را با هم مقايسه نمودند.

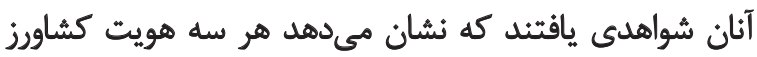

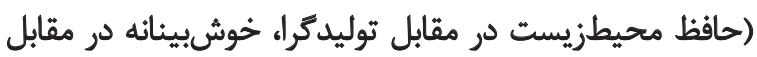

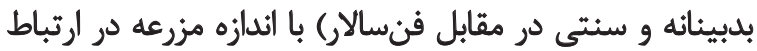

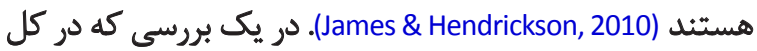

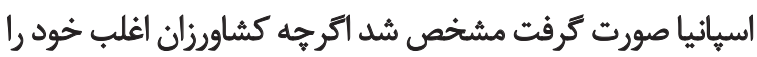

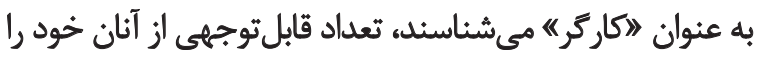

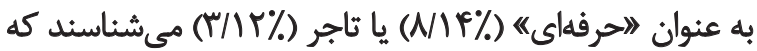

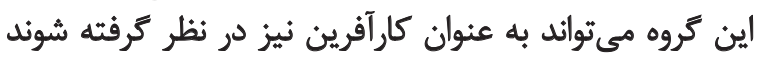

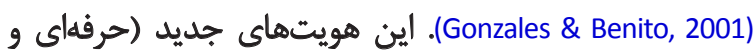
تاجر) در ميان جوانان و كشاورزان تحصيل كرده شايعترند. هويت

2. Resistors

3. Apathists

4. Multifunctionalists

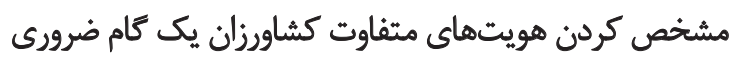

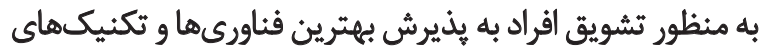

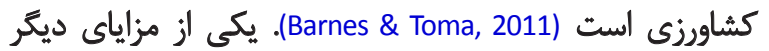

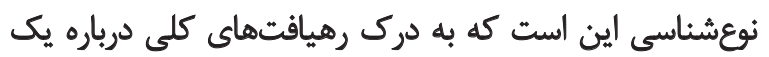

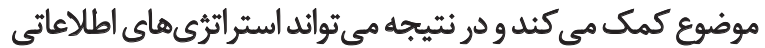

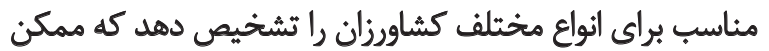

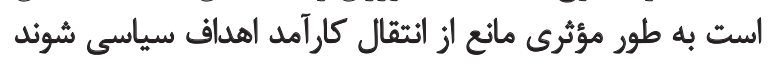

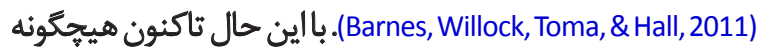

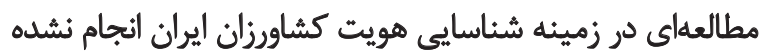

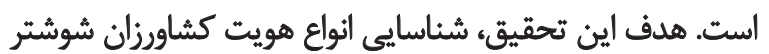
در استان خوزستان با استفاده از روش كيو است است است

شهرستان شوشتر با عرض جغرافيايى الب درجه و ه ه دقيقه

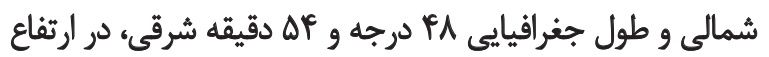

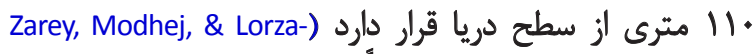

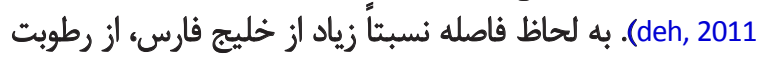

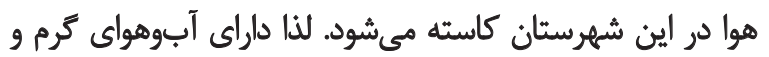

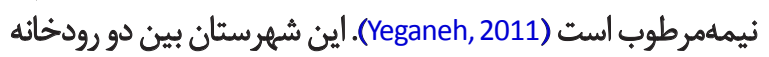
كارون و دز قرار دارد و يكى از قطب إنهاى كشاورزى استان خوزستان به شمار مى آيد (Shoshtari \& Omani, 2012). در اين شهرستان نيز همائند كل كشور، تمركز و سياست دولت

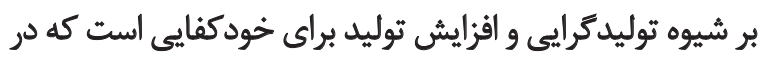

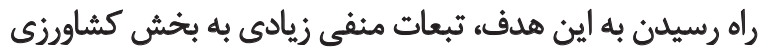

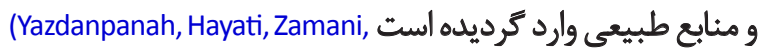
Karbalaee, \& Hochrainer-Stigler 2013; Rezaei-moghadam,

.Karami, \& Gibson, 2005)

با آشكار شدن اين تبعات، حركتهايي در جهت تغيير مسير

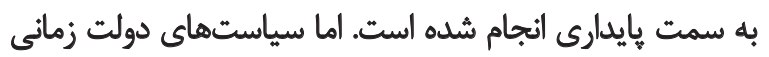

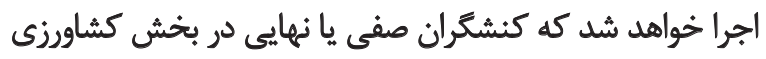

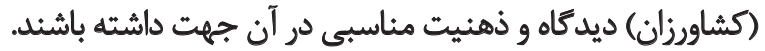

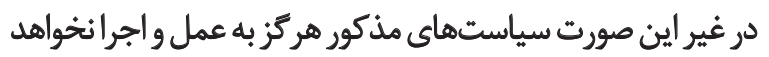

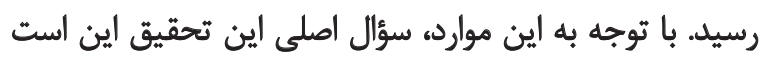

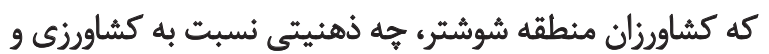

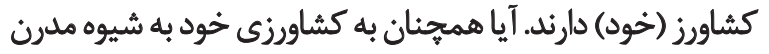

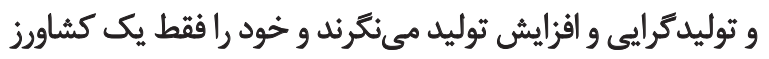

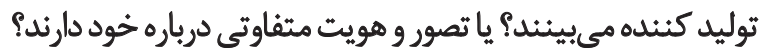
شناخت اين هويتها براى اجرايى شدن سياستهاى دولت إنائ

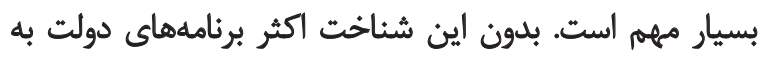

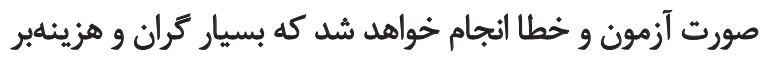

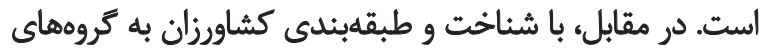

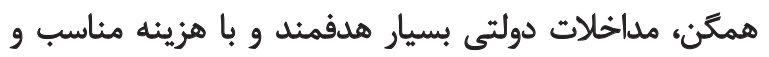

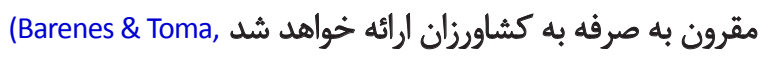

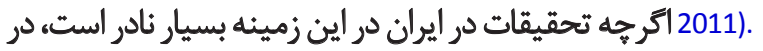


جدول ا. تعداد كويههاى فضاى كفتمان مطالعه بر اساس روش ساختارمئد

\begin{tabular}{|c|c|c|c|}
\hline تعداد كويه & طبقه & تعداد كويه & طبقه \\
\hline$\Delta$ & 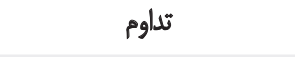 & $p$ & خودتقسيمى \\
\hline$\Delta$ & وإيستكى & $\Delta$ & ارزش هاي اجتماعى \\
\hline f & آيثله & f & خودكارايي \\
\hline$\Delta$ & رشد ملار (تمايل به كسترش) & 11 & ارزشهاى زيستدحيطى \\
\hline 8 & وظيفه كشاوزز & $\Delta$ & حُوشيبنى \\
\hline 8 & وظيفه دولت & 8 & حُودنترلى \\
\hline$\Delta$ & من & 8 & ريسكبذيرى \\
\hline IV & توليدكرايى & $\wedge$ & ن توأور بودن \\
\hline a & كشاورزى الجبارى & $\Delta$ & نكرش نسبت به تكنولوثى \\
\hline$r$ & سنتى & $\Delta$ & استقلال \\
\hline
\end{tabular}

فضاي كُفتمان به معني شُناسايي منابع به

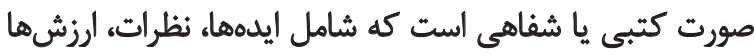

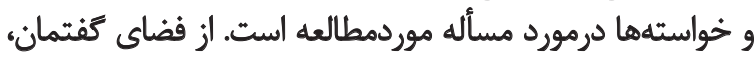

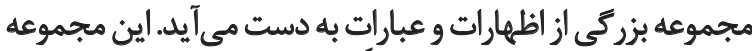

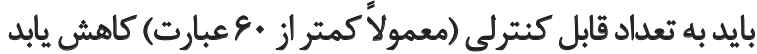
(Cuppen, Breukers, Hisschemöller, \& Bergsma, 2010) يثروهش كه در آن كردآورى فضاى كثتمان به روش ساخت آنافته

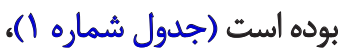

(Gonzales \& Benito, 2001; يس از مرور منابع و يشينه موضوع Mikko Vesala et al., 2007; Vesala \& Vesala, 2010; McElwee, 2008; Burton, 2004; Stenholm \& Hytti, 2014, McGuire et al., (2012، انجام مصاحبه با كشاورزان و كارشئاسان كشاورزى در

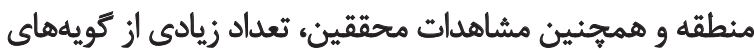
مرتبط به موضوع بر اساس طبقات مربوط و مرثبط مئ با هويت

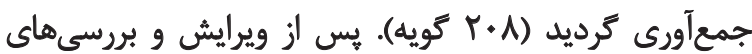

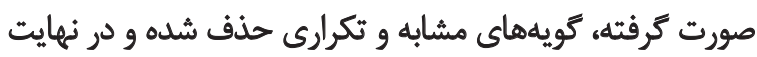

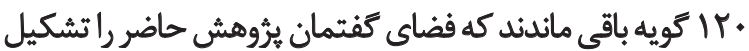

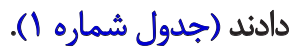

$$
\text { مر حله دوهم: نمونه كيوث }
$$

يك زيرمجموعه از اظهارات انتخاب شده از فضاي كفتمان،

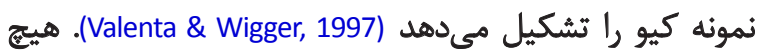

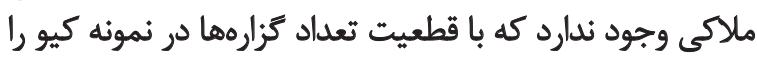

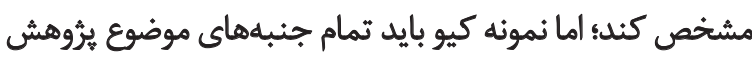

8. Q Sample
كارآفرين در ميان كشاورزاني كه مزارع بزركترى دارند شايعتر

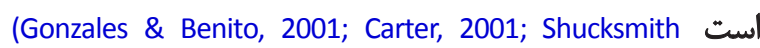

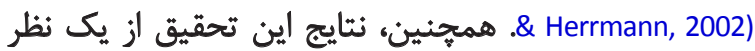

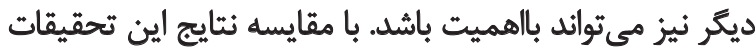

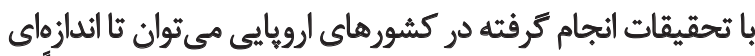

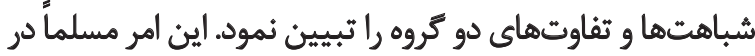

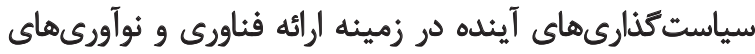

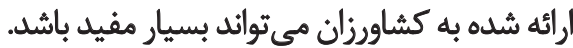

$$
\text { روش ش رشناسى تحقيق }
$$

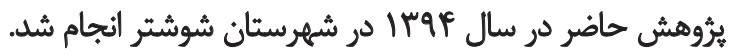

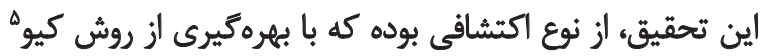

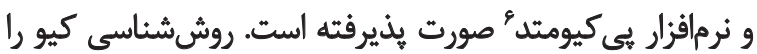

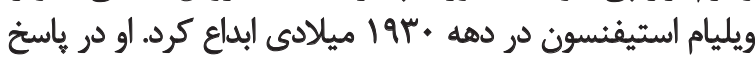

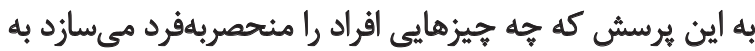

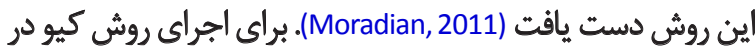

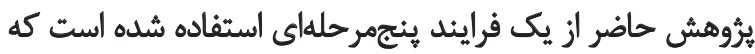

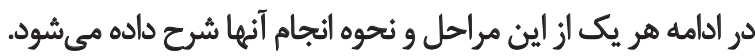

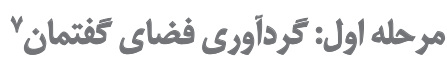

فضاي كُفتمان طيف كستر دماى از بحثها و كُفتمان هما درمورد

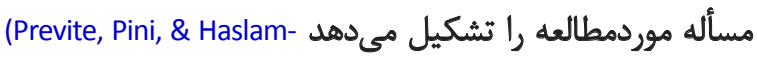
5. Q Methodology
6. PQMethod
7. Definition of the concourse 


\begin{tabular}{|c|c|c|c|c|}
\hline بسيار مخالف (Y-) & مخالف (1-) & بى نظر (.) & موافق (1-) & بسيار موافق (T-) \\
\hline & & & & \\
\hline & & & & \\
\hline & & & & \\
\hline & & & & \\
\hline & & & & \\
\hline & & & & \\
\hline & & & & \\
\hline \multirow[t]{3}{*}{$r$} & & & & \multirow[t]{3}{*}{$r$} \\
\hline & & & & \\
\hline & 9 & & 9 & \\
\hline
\end{tabular}

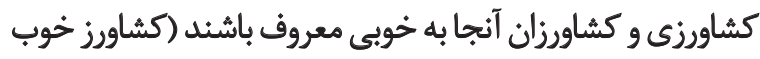

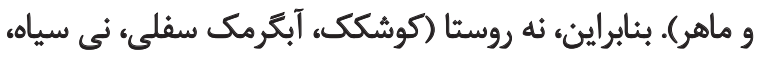

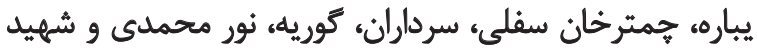

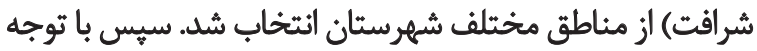

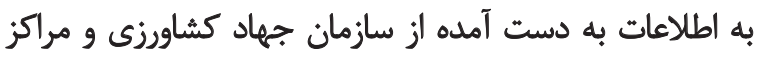

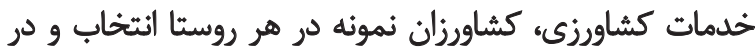
مطالعه شركت داده شدئد.

\section{مرحله همهارم: مرتبسازي كيو"}

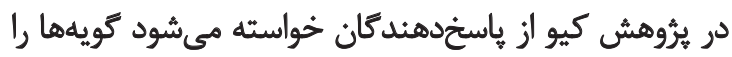

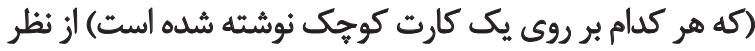

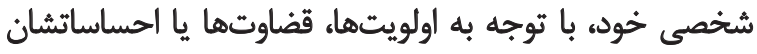

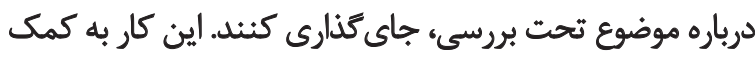

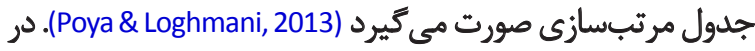

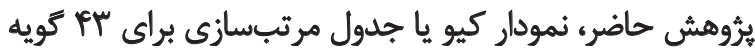

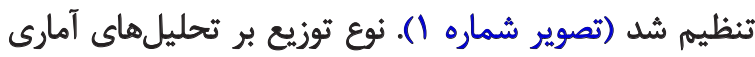

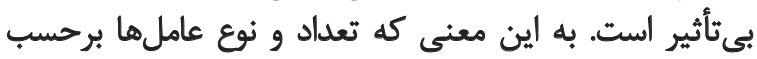

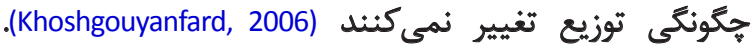

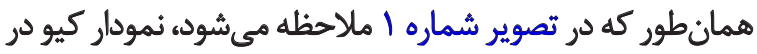

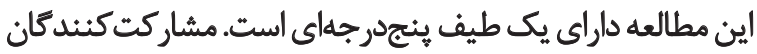

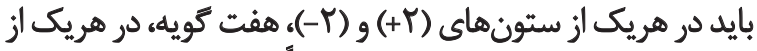

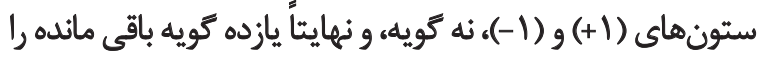

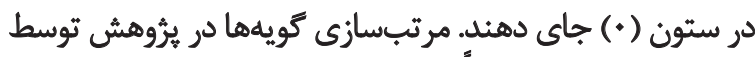
هر مشاركت كنيده تقريباً يك ساعت و نيم به طول طول انجاميد.
ا يوشش دهد.(Ahmadian \& Eslami, 2014) بنابراين فرايند

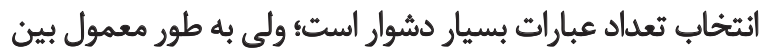

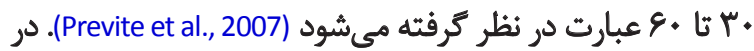

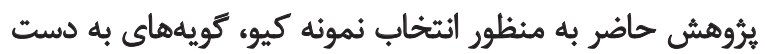

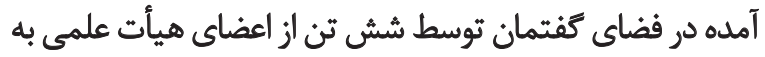

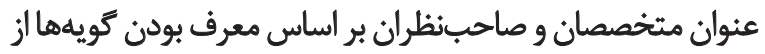

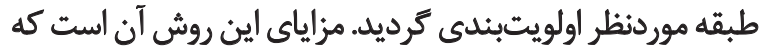

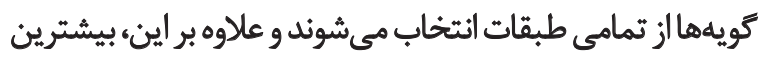

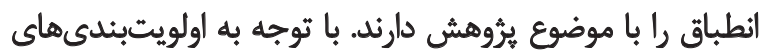

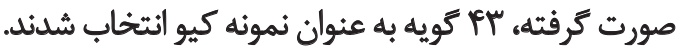

\section{مرحله سوم: انتشخاب مشاركت كثئدكان"}

از آنجا كه برؤوهشهاى انجام شده بر اساس روش رئ كيو، براي

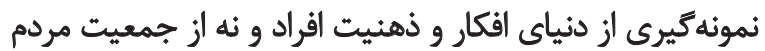

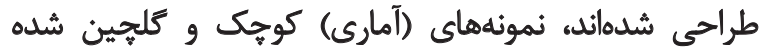

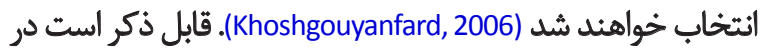

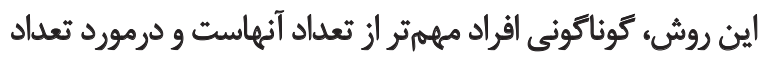

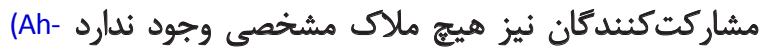

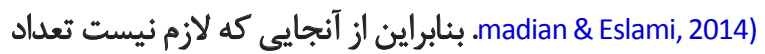

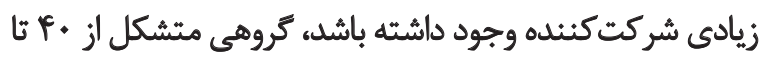

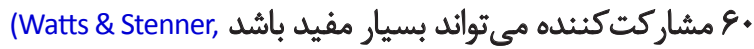

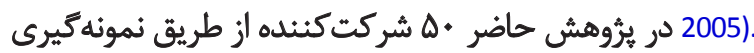

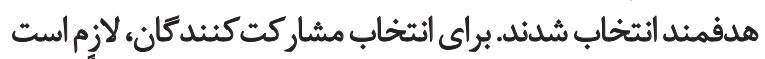

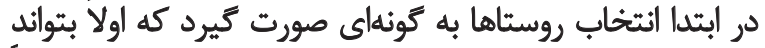

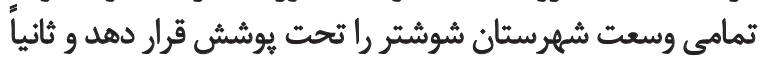


آنجايى كه در اين يرؤوهش كشف نكرش هائ مختلف مدنظر است

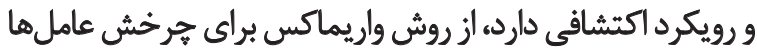
استفاده كرديد و نتايج استخراج شده مورد تجزئه وريه و تحليل قرار كرفت (Ahmadian \& Eslami, 2014).

ياقتهها

با توجه به جدول شماره ؟، كشاورزان مورد بررسى داراى سه

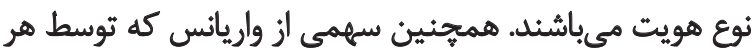

مرحله بئجم: تحليل عاملى كيو"

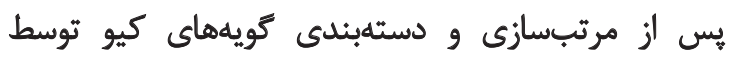

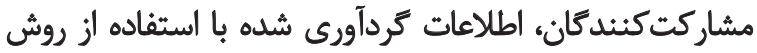

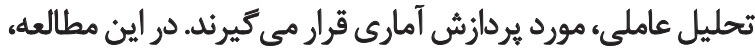

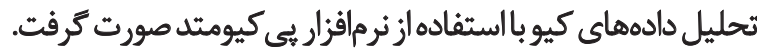

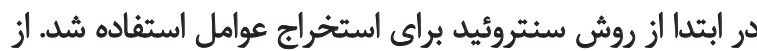

\section{1. $Q$ factor analysis}

جدول T. ماتريس بارهاى عاملى هويت كشاورزان يس از هرخش عاملها

\begin{tabular}{|c|c|c|c|c|c|c|c|}
\hline عامل r & عامل r & عامل | & طبقلبندى كيو & عامل ب & عامل r & عامل 1 & طبقةبندى كيو \\
\hline.$- / \pi f e r$ & $. / . v+q$ & $-. / 4+4 y^{x}$ & re & . Mequex &.$- /$ /q. &.$/ r \cdot 1 r$ & 1 \\
\hline.$- /$ mesp & $.1 \cdot n+9$ & $-\cdot / 4 \cdot e p^{x}$ & rV & . /NEF &.$- / P \Delta T^{x}$ & .1 .098 & r \\
\hline.$- /$ mers & $.1 \cdot v+9$ & $-a p e+p x^{x}$ & rA & $\cdot / 4 \cdot T p^{x}$ &.$- /$ TeVq & .1118 & r \\
\hline . RANA &.$- /$ mpre & . $M M Y A^{x}$ & rq & . lavex &.$- / 7$ ma & $. / T n+1$ & r \\
\hline.$/ 2910$ &.$- /$ rar & $\cdot(A \cdot 9)^{2 x}$ & $r$. & $\cdot\left|\Delta{ }^{\mu}\right| \Delta^{x}$ &.$- /$ MTap & . Near & $ه$ \\
\hline ./\%9/ब &.$- /$ rar & $\cdot / 1 \cdot 9 e^{2 x}$ & ו & . /DIfFex & $-. / r \mid n$ & . MTra & 8 \\
\hline.$/ \% 91 \Delta$ &.$- /$ rar & $\cdot(1 / 9 \cdot 9)^{2 x}$ & $\pi$ & . lortr & -. & 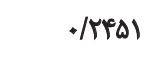 & $r$ \\
\hline.$/ 2910$ &.$- /$ rqr & $\cdot(1 \cdot 9 \cdot 9)^{2 x}$ & r & $.198 . .^{x}$ &.$- /$ req. & . AOTHA & $\wedge$ \\
\hline.$/ 2910$ &.$- /$ rarr & $\cdot(1 / .9)^{2 x}$ & $v_{f}$ & . NAqYX &.$- /$ rAAT & . Mrvar & 9 \\
\hline.$/ 2910$ &.$- /$ rqr & $\cdot / A_{-9 p e x}$ & ro & $\cdot / N I V e^{x}$ &.$- / F A F A$ &.$/ T \Delta \cdot \Delta$ & 1. \\
\hline ./PITr &.$- / T V R$ & . Mequx & q & - Isepax &.$- /$ TOY & . RAVY & 11 \\
\hline.$/$ rass &.$- / \Delta E V \Delta^{x}$ & . TAAY & rr & $\cdot / \Delta \cdot Y \Lambda$ &.$- /$ /Meg & $.18190^{x}$ & ir \\
\hline.$/ T \Delta \& \Delta$ &.$- / A V^{P} \Delta^{x}$ & . /ITr & ra & $\cdot / \Delta r A_{*} x$ & .1 .9 .0 & . MIn & ir \\
\hline . /rApq & $-\cdot / 1 \cdot 10^{x}$ & . MIIT & rq &.$/ P r r^{x}$ & .1 .94$. & . TAIT & if \\
\hline . MTIE & $-\cdot / r r v$ & $\cdot / N \cdot g^{2 x}$ & r. & . / Rarr & . Rarr & $-* /$ rif. & 10 \\
\hline.$/ r .94$ & $-.19999^{x}$ &.$/ 19.4$ & H & . $/ \Delta r \mid a^{x}$ &.$- /$ /Tqq & - Naqr & 18 \\
\hline$. / m+1$ &.$/ m M \Delta$ &.$- / r \Delta \cdot \wedge$ & rr & . IAPT. & $-. / 9 v 1 . x$ & . MTrY & IV \\
\hline.$/ .99 \%$ & $-.10 \Delta \cdot 1$ & $\cdot \mid \varphi+\varphi+x$ & pr & . Meqpx &.$- /$ rq\%. & . & M \\
\hline.$/ 9119$ & $-\cdot M M 1^{x}$ & . TIV & pr & . / Meqpx &.$- / \% q 4$. &.$\pi \cdot 1 r$ & 19 \\
\hline.$/ 2989$ &.$- / \Delta E V \Delta^{x}$ & . TSAY & po & - IAvrex & $-\cdot($ rva) &.$/ m n^{\prime}$ & r. \\
\hline . 1.945 & $-\cdot / \Delta \Delta \cdot 1$ & $=18+4+x$ & pq & $198 . .^{x}$ &.$- /$ TPq. & . & $M$ \\
\hline.$/ r \cdot q r$ & $-.19999 x$ & $. / 1 q . r$ & pr & $.1 .+11$ &.$- /$ Mrrex & אוrא & $\pi$ \\
\hline . TSASD & $-\cdot / A V f^{x} \Delta^{x}$ & . & ra & $.1 .+11$ & - & ATrA & זr \\
\hline.$/ 994$ & $-\cdot \mid \Delta \Delta \cdot 1$ & $\cdot \mid 8+4 \cdot x$ & $p q$ &.+ .11 & XיקTr/ & אוTMA & $r F$ \\
\hline זיזרא. & . /Tary & $-\bullet /$ mife & $\Delta$. & $.1 . .11$ & - MTrex & ATrA & To \\
\hline
\end{tabular}


جدول ץ. واريانس تبيين شده هر عامل

\begin{tabular}{|c|c|c|c|}
\hline عامل سوم & عامل دوم & عامل اول & \\
\hline$r+\%$ & $r T \%$ & $19 \%$ & درصد واريانس تبيين شلده \\
\hline
\end{tabular}

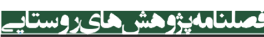

مي دهد، در عامل اول، كويه لكشاورزان بايد همجهون كارمئدان

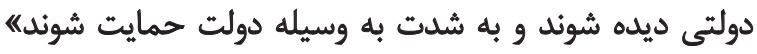

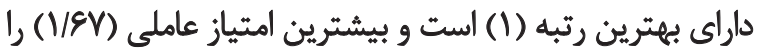

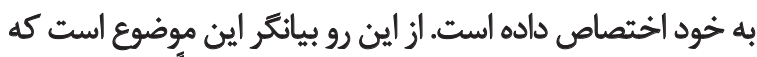

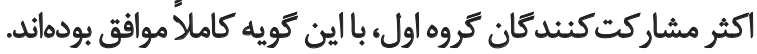

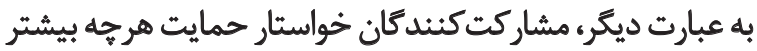

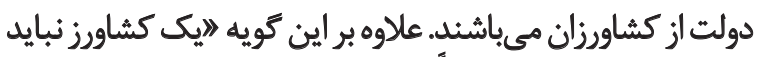

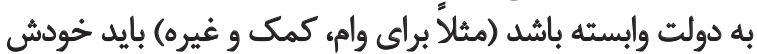

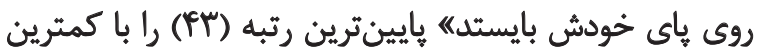

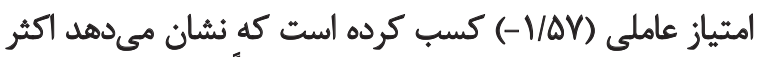

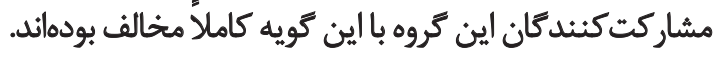
در عامل دوم، كويه لايك كشاورز خوب بايد محصولات متنوعى كنى

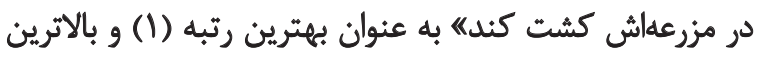

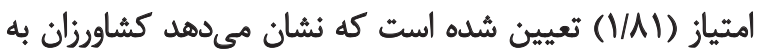

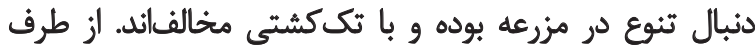

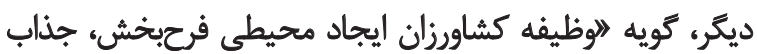

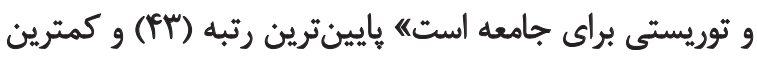

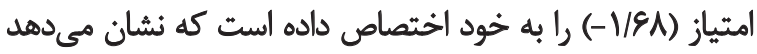

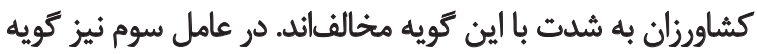

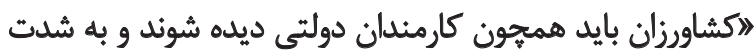

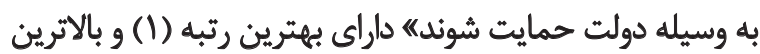

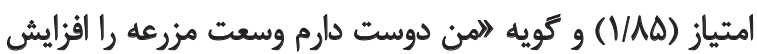
و كارم را كسترش دهمه هايينترين رتبه (FI) و و كمترين امتياز

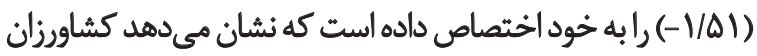

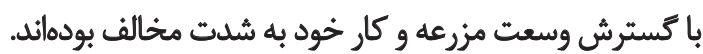

\section{مشتخمات بين عاملها}

در اين مرحله، نرمافزار اطلاعاتي مشخصات عامل هاى استخراج

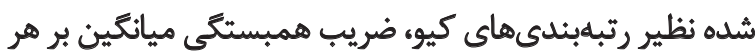

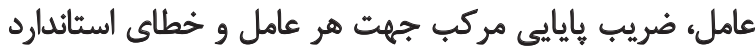

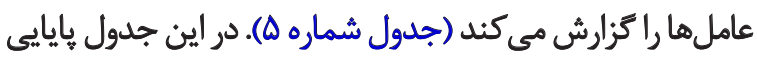

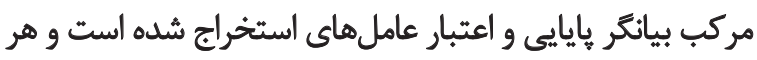

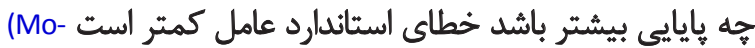
(hammadi Tamari, Ahmadvand, \& Ghasemi, 2014) جدول شماره ه، عاملها از اعتبار خوبي برخوردارند و ميزان

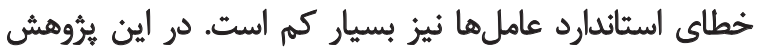

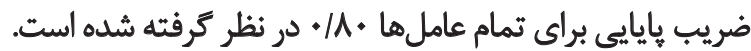

عامل تبيين مي شود نيز در جدول شماره ب قابل مشاهده است.

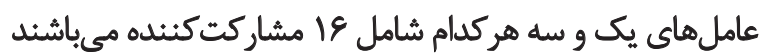

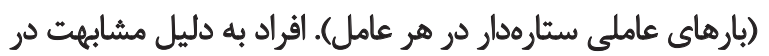

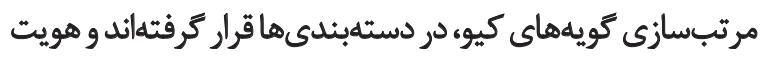

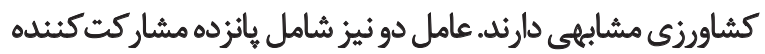

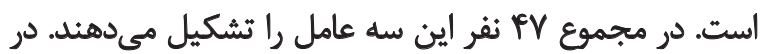

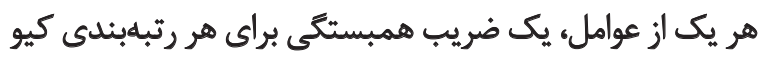

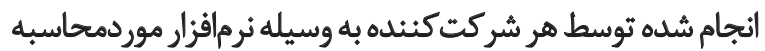

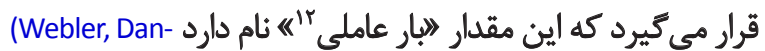
ielson, \& Tuler, 2009)

به عبارت ديكَ، بار عاملى همبستگى بين هر رتبهبندى

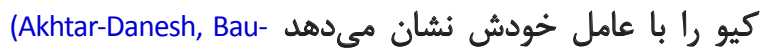

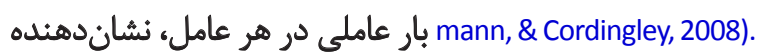

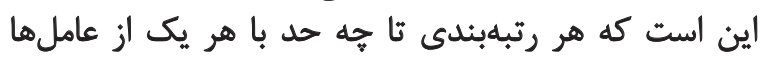

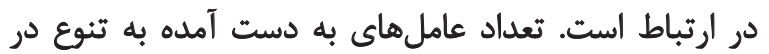

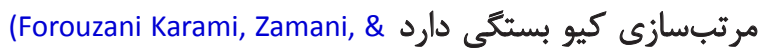

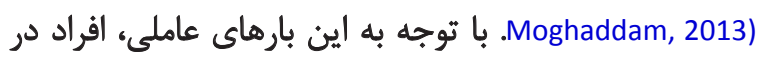

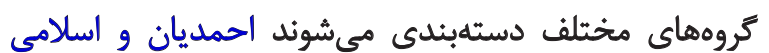
(T. IF)

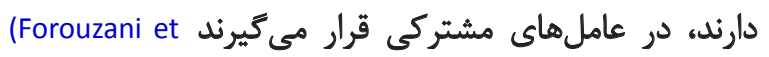

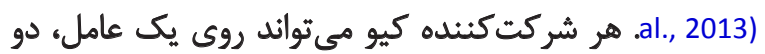

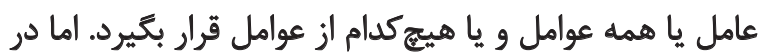

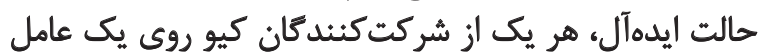

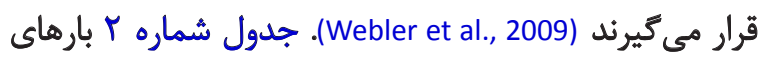

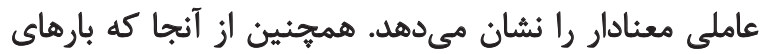

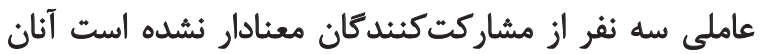

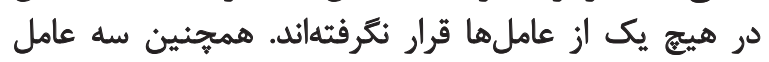

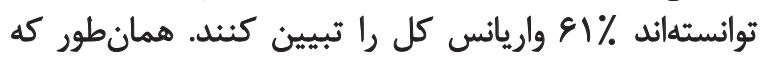

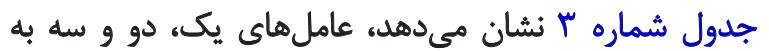

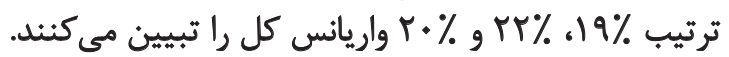

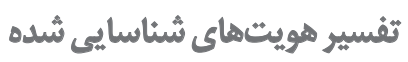

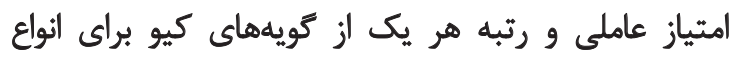

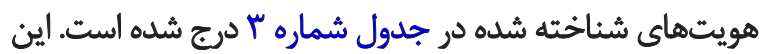

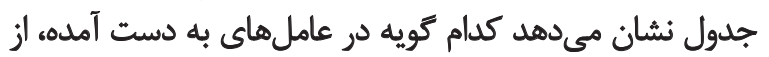

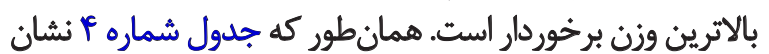

12. Factor loading 
جدول F. ميزان امتيازهاى عاملى و رتبه هر يك از عبارات كيو براي هويتهاي شناخته شده

\begin{tabular}{|c|c|c|c|c|c|c|}
\hline \multicolumn{2}{|c|}{ 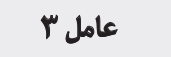 } & \multicolumn{2}{|c|}{ عامل r } & \multicolumn{2}{|c|}{ 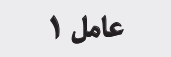 } & \multirow{2}{*}{ كويه } \\
\hline رتبه & امثياز & رتبه & امثياز & رتبه & 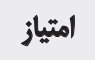 & \\
\hline 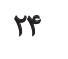 &.$- / 19$ & ro &.$- / 11$ & $\Delta$ & $1 / 4$ & 1. كسى كه خيلى به فكر محيط زيست باشد ثا توليد، كشاورز نيست. \\
\hline ir & .199 & $m$ & $-1 / \cdot f^{e}$ & M &.$/ \pi r$ & r. كسى كه بتواند بدون استُفاده از كود و سه شيمياييى توليد كند، كشاورز واقعى است. \\
\hline 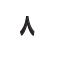 & $1 / 19$ & ra & $-1 / 48$ & $r$ & $1 / R{ }^{\prime}$ & ب. كشاورز خوب فردى است كه محصولات و ارقام جديدى را كشت نمايل. \\
\hline r. & $-1 / r^{m}$ & 1. &.$/ v 8$ & $M$ & .1 & f. به نظر من در كشاورزى بايد از ئيروى أثسائى بسيار كمى استفاده كرد و بيشتر از ادوات و ابزار بهره برد. \\
\hline r & $-\cdot / r$ & 18 &.$/ 4$ & rq & $-1 / 49$ & هـ من دوست دارم فرزنلانمم هم به شغل كشاورزى روى آورند. \\
\hline 9 & $1 / .9$ & $r v$ & $-1 / 1 f$ & 9 & . IAV & ع كشاورزان واقعى نبايد كار ديكرى در خارج از مزرعه داشته باشند. \\
\hline ra & $-1 / r$ & pq & $-\cdot / 4$ & ra & - & V. به نظر من يك كشاورز خوبه جديدترين تكنولوزى هاى كشاورزى را براى حلاكثر سود استفاده مي كنلد. \\
\hline זr & $-\bullet / M^{f}$ & $\mu$ & VIF & if & $-* / \pi$ & A يك كشاورز بايد زمانى كه كشاورزى سودآور نيست هم كشاورزى را الدامه دهد و مزرعه خود را رها نسازد. \\
\hline 1. & ./AT & $M$ & $-+/ 9 f$ & if & $\circ / \mathrm{N}$ & 9. به نظر من كشاورز خوب كشاورزى است كه با روشهاى كذشتهن و قديمى كشاورزى كند. \\
\hline r. & $\cdot / \cdot V$ & rr & $+/$ & ir & $\cdot M^{e}$ & •. كثاورزان وظيفه دارند كه سلامتى زمين، آب و محيط كثاورزى خود را حفظ كنند. \\
\hline$r$ & $M^{e}$ & MT & -.18. & $r$ & $1 / 49$ & 11. كشاورزى شُعل مخصوص روستا الست و فرد بايد روستايع باشد و تجربه اين كار را داشته باشد. \\
\hline 19 &.$/ 1 r$ & 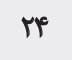 & $-.1 \cdot f$ & $r$ & $-1 / m$ & r. . هن دوست دارم شغل ديكرى غير از كشاورزى داشته باشم ولى سرمايه، مهارت و امكائش را ندارم. \\
\hline Pi & $-1 / r a$ & if &.$/ 18$ & iv &.$/ \pi$ & rا. من هيتوائم هوفقيت ششغل كشاورزيم را از طريق بازاريابى و ارتباط با هشتريان بهتر كنم. \\
\hline ro & $-* / M$ & iv & |r| & r. & $-* N$ & fl ا. به نظر من يك كشاورز بايد سعى كند روشهاى جديد كشاورزى رازودتر از ديكران، به كار كيرد. \\
\hline$\Delta$ & $1 / R T$ & 19 &.$/ M$ & r. &.$/ M$ & ها ـ وظيفه اصلى كشاورزان برآورده كردن نيازهاي انسانهاي فعلى اسيت نه حفظ منابع براى نسل هاى آينده. \\
\hline Tr & $-+/ Q 1$ & Ir & ./FY & 18 & $\cdot / P V$ & عا. من قصد دارم در آينده علاوه بر كشاورزى به مشاغل ديكرى نيز بيردازم. \\
\hline$r$ & $1 / 4+$ & Hi & $-1 / 8$. & $r$ & $1 / \mathbb{A}$ & IV ا. به نظرم كسى كه خود را يك ثاجر يا كاسب مى داند نمى ثوائد يك كشاورز باشد. \\
\hline rr & $-1 / \Delta)$ & $\Delta$ & D/AT & ש & -.14 & 11. من دوست دارم وسعت مزرعه را افزايش و كارم را كسترش دهم. \\
\hline r & $-\bullet / 1$ & 11 & $\cdot / V \Delta$ & TV & $-\infty / 41$ & 19. به نظر من يك كشاورز بايد به خاطر حفظ محيط زيست توليد خود را كاهش دهل. \\
\hline IV & . & 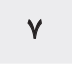 & VIV & $r r$ & $.1 \cdot \Delta$ & • آ. مهمترين هدف من در كشاورزى برآورده كردن نيازهاى مردم كشورم و تأمين رقاه آنهاست. \\
\hline M &.$/ 1 r$ & $M$ &.$/ T Y$ & 10 & .189 & آ. من مطمتنم كه ميتواثم در كسب و كار هم به اندازه كشاورزى موفق باشهم. \\
\hline r. & $-\cdot M$ & ir & $\cdot / M^{e}$ & TA & $-\cdot / M$ & r. كشاوزان نبايد به خاطر تخريب آب يا خاك مورد سؤال قرار كيرند. \\
\hline 18 &.$/ M E$ & m & -.18 & ו & $-\cdot 14$ & 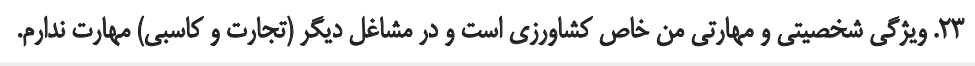 \\
\hline Hr & $-\cdot / M^{p}$ & re & $-\cdot / \pi r$ & rq & $-\cdot \operatorname{lep}$ & 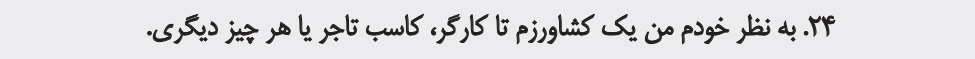 \\
\hline$r$ & $|/ A|$ & ro & $-1 / 14$ & 1. & - /Ar & ه广. وظيفه اصلى كشاورزان بايد توليد غذاى سالم باشده ارزانى خيلى مهنه ثيست. \\
\hline 1 & $1 / 1 / \Delta$ & $M$ & $-1 / \&$ & 1 & $1 / 8 V$ & عץ. كشاورزان بايد همجحون كارمندان دولتى ديده شوند و به شلت بوسيله دولت حمايت شوند. \\
\hline$m$ & $-\cdot / 10$ & 9 & $\cdot|\Lambda|$ & ir & $\cdot M^{\infty}$ & وr. مهمترين هدف من در كشاورزى حلاكثر سازى درامل و كسب سود اقتصادى است. \\
\hline r & $\mid / 91$ & f. & $-1 / \Delta \&$ & 1 &.$/ 9 \gamma$ & •"ب. من ترجيح مى دهم كارك استخدام نكنم و همه كارها را خودم انجام دهم. \\
\hline rq & $-1 / r 4$ & $r$ & $1 / 89$ & rA & $-\cdot / \Delta \Delta$ & آل. به نظر من دولت بايد كود و سموم شيميانيى را به وفور و با قيمت الوزان در خدمت كشاورزان قرار دهد. \\
\hline$\pi$ & $-\cdot|\wedge|$ & $p$ & $1 / F V$ & Pr & $-1 / \Delta V$ & Tس. كشاورز نبايد به دولت وابسته باشد (مثلاً براى وام و كمى و غيره) بايد خودش ووى ياي خودش بايسثلد. \\
\hline
\end{tabular}




\begin{tabular}{|c|c|c|c|c|c|c|}
\hline \multicolumn{2}{|c|}{ 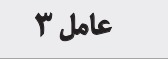 } & \multicolumn{2}{|c|}{ 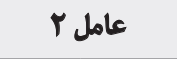 } & \multicolumn{2}{|c|}{ 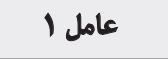 } & \multirow{2}{*}{ كويه ها } \\
\hline رتبه & 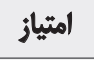 & رتبه & 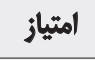 & رتبه & امثياز & \\
\hline re & $-+/ f \Delta$ & $r V$ & $-\cdot / M$ & re & $-+/ r a$ & سٓ. به نظر من روش هاى جديد كشاورزى روش هاى خوبى نيستند. \\
\hline re & $-1 / M$ & $r$. & .118 & f. & $-1 / 42$ & بآ. به نظر من يك كشاورز خوب كشاورزى است كه همه درأمد خود را از كشاورزى تأمين مى كثد. \\
\hline$M$ & $-\oplus / \cdot 0$ & $M$ & .11 & ro & $-\cdot / \mathrm{AV}$ & ها" مهمترين هدف من در أنجام كار كشاورزى توسعه و ييشرفت روسثاى محل زندكيم است. \\
\hline 10 &.$/ 149$ & $r$. &.$- / 4 t$ & 19 & $\cdot / \pi V$ & عس. كشاورز كسى است كه فقط در زمينه كشاورزى مهارت داشته باثلد. \\
\hline$r \Delta$ & $-+/ 4$ & 1 & $|/ A|$ & Mr & $-V / \Delta V$ & Vע. يك كشاورز خوب بايد محصولات متنوعى در مزرعلاش كشت كند. \\
\hline MA & $-+/ 94$ & ir &.$/ \Delta A$ & rr & $-+/ A r$ & ها. به نظل من دولت بايد حد معينى براى استفاده از سم و كود را تعيين كند. \\
\hline rr & $-1 / \times 9$ & w & $-1 / / 1$ & $m e$ & $-4 / A \gamma$ & وَّ. من مى توانم محصولات خود را به طور مستقيم در بازار توزيع كنم. \\
\hline$q$ & $1 / m$ & $A$ & $1 / 1$. & r & .10 & 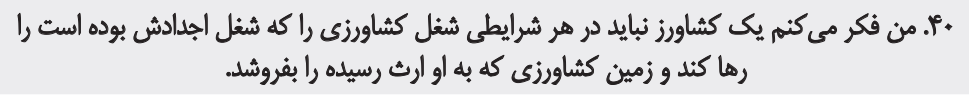 \\
\hline 19 &.$/ 179$ & $r A$ & $-\cdot / r v$ & 8 & $1 / m p$ & الم. من به شغل كشاورزى بسيار وابسته نيستم و اكر شغل مناسبترى ييلا كنمى فوراً كشاورزى را رها مي كنم. \\
\hline$r$ & $-1 / r$. & 8 & $1 / 7 q$ & Pi & $-V / A r$ & rم. كشاورز خوب كشاوزيىست كه تا حلد ممكن سعى كند مزرعهاش راكسترش دهل. \\
\hline rq & $-\bullet / E T$ & r & $\mathscr{H}+\mu$ & س & $-\cdot / \Lambda r$ & "آه. به نظر من دولت بايد قوانين محكم و ستختى در مورد استفاده از منابع آيى و خاكى براى كشاوزي بكذارد. \\
\hline 11 & $\cdot M$ & $\pi$ & $-1 / 8 \wedge$ & $r$ & Var & 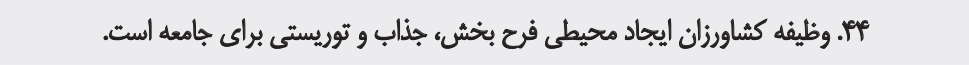 \\
\hline ir & . No & rq & $-1 / 18$ & 11 &.$/ 1$ & 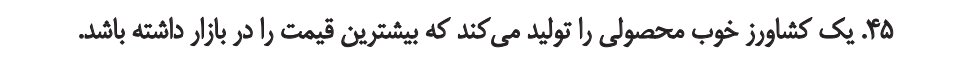 \\
\hline
\end{tabular}

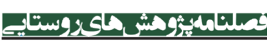

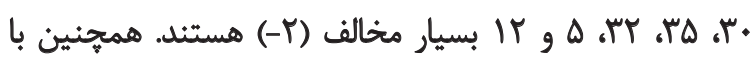

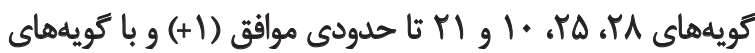

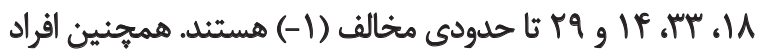

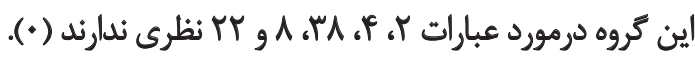

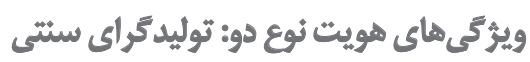

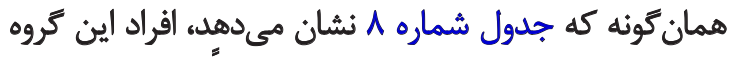

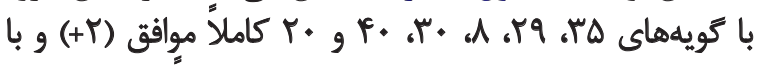

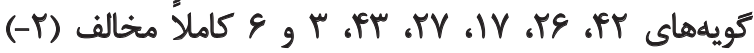

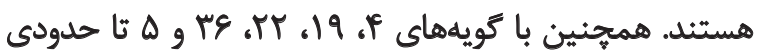

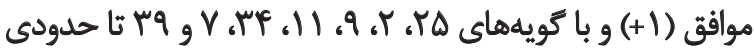

\section{كويلها و امثيازات عاملى آتمها در هر عامل}

همانوطور كه ملاحظه مي شود، جدول شماره 9 جايكاه

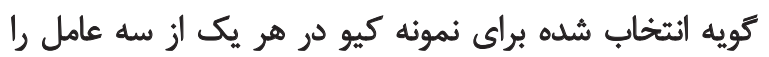

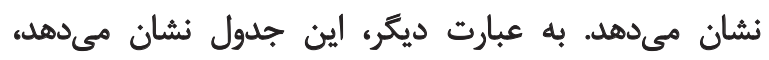

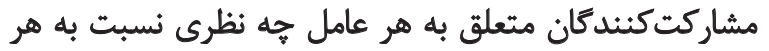

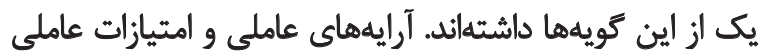

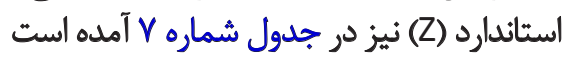

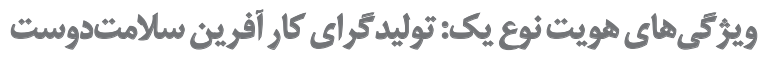
همان كونه كه جدول شماره \& نشان مي دهد، كشاوززان اين زروه

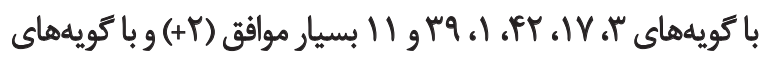

جدول ه. مشخصات عاملها

\begin{tabular}{|c|c|c|c|}
\hline \multicolumn{3}{|c|}{ عاملها } & \multirow[b]{2}{*}{ هشخصات عاملها } \\
\hline عامل ب & re عامل T & عامل 1 & \\
\hline 18 & 10 & 18 & تعداد اقراد در هر عامل \\
\hline 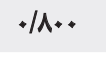 & $\cdot / A+$. & $+/ A+*$ & ميانكين ضريب بايايعى \\
\hline . / UA & - MuF & ./RA & يايايي مركب \\
\hline.$/ 1 T F$ &.$/ I T A$ &.$/ M T E$ & خطاى استاندارد عامل ها \\
\hline
\end{tabular}

\section{تملئمس}


جدول 8. 5ويهها

\begin{tabular}{|c|c|c|c|}
\hline$\frac{z}{5}$ & $\frac{\vec{c}}{5}$ & $\frac{5}{5}$ & 1هائ \\
\hline$\cdot$ & $\cdot$ & r & كسى كه خيلي به فكر محيط زيست باشد تا توليدء كشاوزز نيست. \\
\hline 1 & -1 & $\cdot$ & كسى كه بتواند بلون استفاده از كود و سه شيميايعى توليد كند، كشاورز واقعى است. \\
\hline 1 & $-r$ & r & كشاورز خوب فردى است كه محصولات و ارقام جديدى را كشت نمايد. \\
\hline$-r$ & 1 & • & به نظطر من در كشاوزي بايد از نيروى اثسائى بسيار كم استفاده كرد و بيشتر از ادوات و ابزار كشاورزى بهره برد. \\
\hline-1 & 1 & $-r$ & من دوست دارم فرزندانم هم به شعل كشاورزى روى آورند. \\
\hline 1 & $-r$ & 1 & كشاورزان واقعى نبايد كار ديكرى در خارج از مزرعه داشته باشند. \\
\hline$-r$ & -1 & $-r$ & به نظر من يك كشاورز خوبه جديلترين تكنولوزى هاى كشاورزى را براى حداكثر سود اسثفاده مى كند. \\
\hline-1 & r & - & به نظر من يك كشاوز خوب بايد حتى زمانى كه كشاورزى سودآور نيست باز هم كشاوزي را ادامه دهل و مزرعه خود را رها نسازد. \\
\hline 1 & -1 & 1 & له به نظر من كشاوز خوب كشاوززى است كه با روشهاى كذشته و قديمى كشاوزي كند. \\
\hline • & • & 1 & كشاوزان وظيفه دارند كه سلامتى زمين، آب و محيط كشاورزى خود را حفظ كنند. \\
\hline r & -1 & r & كشاورزى شغل روستا است و فرد براى اين كار بايد روستايع باشد و تجربه اين كار را داشته باشد. \\
\hline • & • & $-r$ & من دوست دارم شغل ديكرى غير از كشاورزى داشته باشم ولى سرمايه، مهارت و امكاناتش را ندارم. \\
\hline$-r$ & 1 & $\cdot$ & من مىثوانم موفقيت شغل كشاوززيم را الز طريق بازاريائى و ارتباط با مشتريان بهتر كثم. \\
\hline - & • & -1 & به نظر من يك كشاورز بايد سعى كثد روشهاى جليد كشاوزى را زودتر از اينكه ديكران به كار كيرند، به كار كيرد. \\
\hline r & $\cdot$ & - & 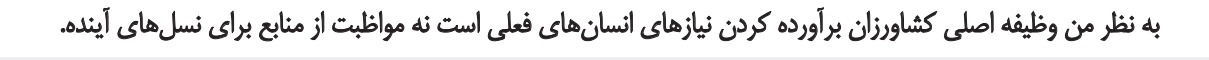 \\
\hline - & 1 & 1 & من قصد دارم در آينده علاوه بر كشاوزى به مشاغل ديكرى نيز بهردازم. \\
\hline r & $-r$ & r & به نظرم كسى كه خود را يك ثاجر يا كاسب مي دائد نمىتوائد يك كشاورز باشد. \\
\hline$-r$ & r & -1 & من دوست دارم وسعت مزرعه را افزايش و كارم را كسترش دهم. \\
\hline • & 1 & $\cdot$ & به نظر من يك كشاورز بايل به خاطر حفظ محيط زيست توليد خود را كاهش دهد. \\
\hline + & r & + & مهمترين هدف من در كشاورزى برآورده كردن نيازهاى مردم كشورم و تأمين رفاه آنهاست. \\
\hline • & • & 1 & من مطمتنم كه مىثوانم در كسب و كار هم به اثدازه كشاورزى موفق باشهم. \\
\hline-1 & 1 & $\cdot$ & كشاورزان نبايد به خاطر تخريب آب يا خاك مورد سؤال قرار كيرند. \\
\hline 1 & -1 & $\Rightarrow$ & 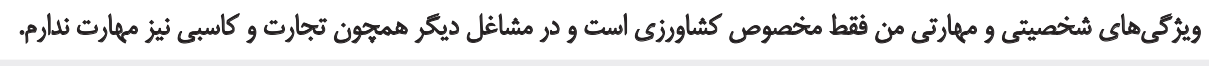 \\
\hline-1 & . & -1 & به نظر خودم هن يك كشاورنم تا كاركر، كاسب تاجر يا هر جيز ديكرى. \\
\hline$r$ & -1 & 1 & وظيفه اصلى كشاورزان بايد توليد غَذاي سالم باشلده ارزانى خيلى مهم نيست. \\
\hline$r$ & $-r$ & $r$ & كشاوزان بايد همجون كارمندان دولتي ديله شوند و به شلت بوسيله دولت حمايت شوند. \\
\hline . & 1 & 1 & مهمثرين هدف من در كشاورزى حداكثر سازى درامل و كسب سود اقتصادى است. \\
\hline$r$ & $-r$ & 1 & من ترجيح مى دهم كاركر استخدام نكنم و همه كارها را خودم انجام دهم. \\
\hline$-r$ & $r$ & -1 & به نظر من دولت بايد كود و سموم شيميايي را به وفور و با قيمت الززان در خلمث كشاورزان قرار دهل. \\
\hline-1 & $r$ & $-r$ & يك كشاورز نبايد به دولت وابسته باشد (مثلاً براى والم و كمى و غيره) بايد خودش روى يايى خودش بايستد. \\
\hline
\end{tabular}




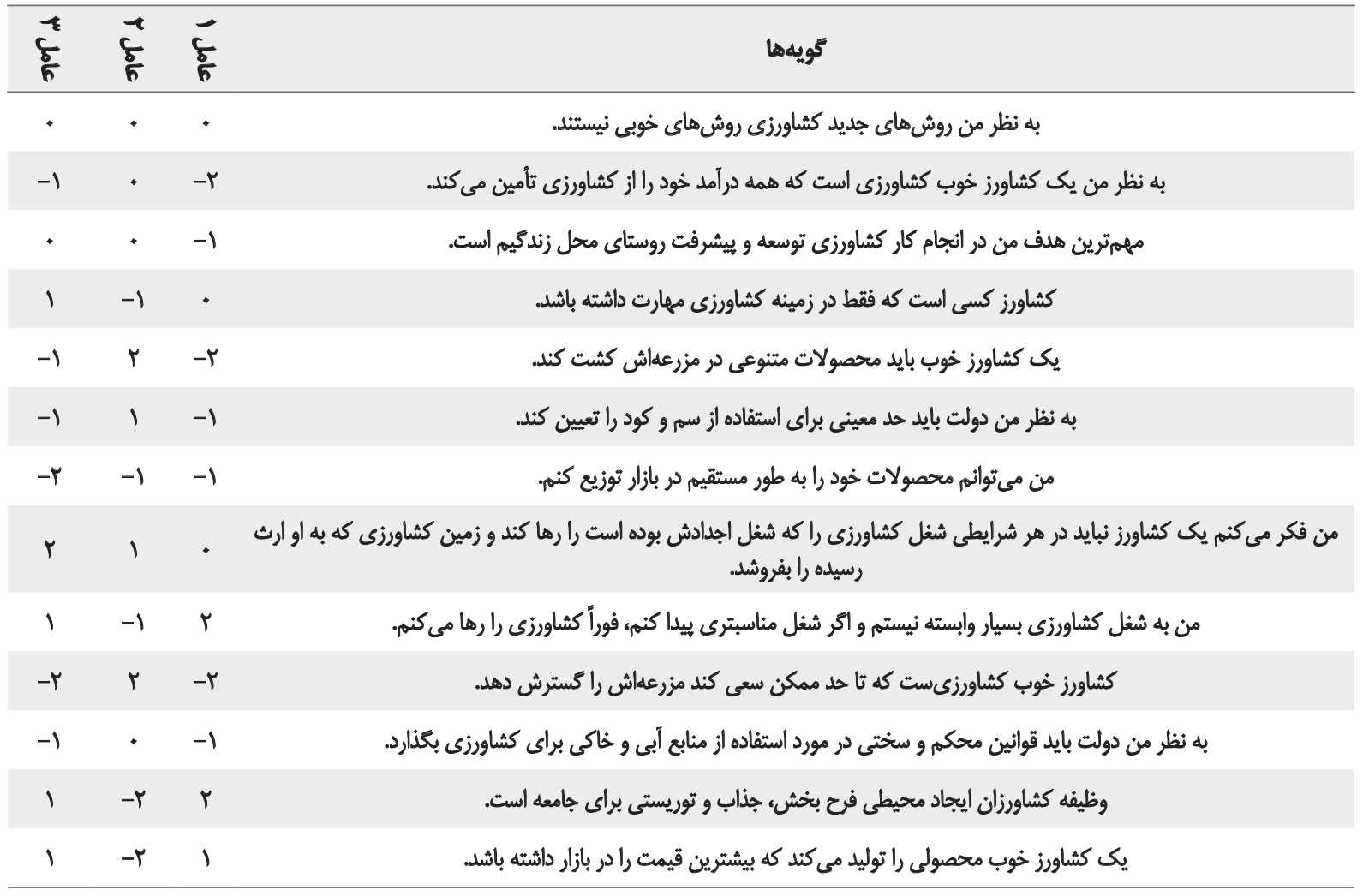

جدول V. آرايههاى عاملى و امتيازات عاملى استائدارد (Z)

\begin{tabular}{|c|c|c|c|}
\hline 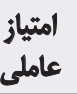 & نمرات استاندارد & 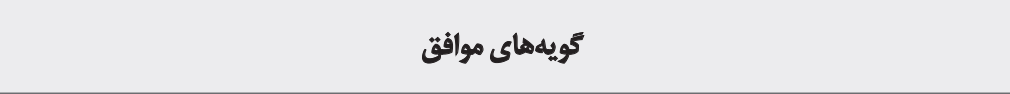 & شماره تُويه \\
\hline r & V/gr & كشاورز خوب فردى است كه محصولات و ارقام جديدى را كشت نمايد. & $r$ \\
\hline r & $V / \Delta A$ & به نظرم كسى كه خود را يك ثاجر يا كاسب مي دائد نمى توائد يك كشاورز بانش. & IV \\
\hline r & V/ar* & وظيفه كشاورزان ايجاد محيطى فح بخش، جذاب و توريستى براى جامعه است. & Pr \\
\hline r & $1 / \varphi^{*}$ & كسى كه خيلى به فكر محيط زيست باشد تا توليد، كشاورز نيست. & 1 \\
\hline r & $1 / m+$ & من به شغل كشاورزى بسيار وابسته نيستم و اكر شغل مناسبترى بيدا كنم، فوراً كثاورزى را رها مىكنم. & rq \\
\hline r & $1 / r q$ & كشاورزى شغل مخصوص روستا است و فرد برايى اين كار بايد روستايى باشد و تجربه اين كار را داشته باششد. & 11 \\
\hline 1 &.$/ 9 r^{\circ}$ & من ترجيح مىدهم كاركر استخدام نكنم و همه كارها را خودم انجام دهم. & ra \\
\hline 1 & . /AY* & 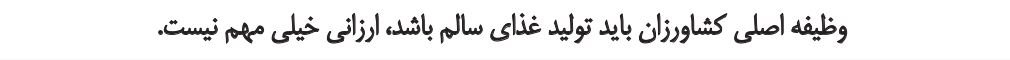 & TQ \\
\hline 1 &.$M e$ & كشاورزان وظيفه دارند كه سلامتى زمين، آب و هحيط كشاورزى خود را حفظ كنتد. & 1. \\
\hline 1 & .189 & 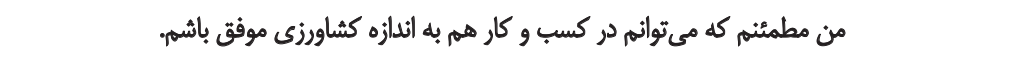 & M \\
\hline • &.$/ M$ & كسى كه بتواند بدون استفاده از كود وسم شيميايى توليد كند، كشاورز واقعى است. & r \\
\hline • & . & به نظلر من در كشاوززى بايد از نيروى أتسان كم استفاده كرد و بيشتر از ادوات و ابزار كشاورزى بهره برد. & r \\
\hline - & $\%$ & 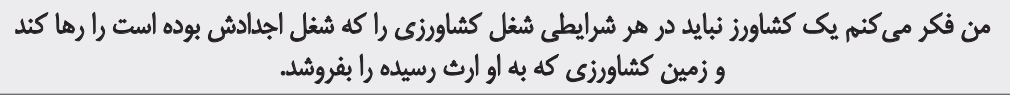 & rı \\
\hline
\end{tabular}




\begin{tabular}{|c|c|c|c|}
\hline عاملى المياز & $\begin{array}{c}\text { نمرات اسثاندارد } \\
\text { (Z) }\end{array}$ & كويههاى مخاف & شُماره كَويه \\
\hline - & $-\cdot / M+$ & يى كشاورز بايد زمانى كه كشاورزى سودآور نيست هم كشاورزى را الدامه دهل و مزرعه خود را رها نسازد. & A \\
\hline+ & $-\cdot / M+*$ & كشاورزان نبايد به خاطر تخريب آب يا خاك مورد سؤال قرار كيرند. & rr \\
\hline-1 & $-\cdot / \Delta \Delta^{*}$ & به نظر من دولت بايد كود و سموم شيميايع را به وفور و با قيمت ارزان در خدمت كشاوززان قرار دهد. & ra \\
\hline-1 & $-\cdot N \cdot *$ & به نظر من يك كشاوز بايد سعى كثلد روشهاي جلديد كشاورزى رازودتر از ديكران، به كار كيرد. & if \\
\hline-1 & $-\cdot / A r^{*}$ & ههمترين هدف من در انجام كار كشاورزى توسعه و ييشرفت روستاى محل زندكيم است. & $m$ \\
\hline-1 & $-\cdot / \mathrm{U}^{*}$ & من دوست دارم وسعت مزرعه را افزايش و كارم را كسترش دهم. & il \\
\hline$-r$ & $-1 / M^{2 *}$ & من دوست دارم شعل ديكرى غير از كشاورزى داشته باشهم ولى سرمايه، مهارت و امكائش را أدلارم. & ir \\
\hline$-r$ & $-1 / r^{*}$ & من دوست دارم فرزندانم هم به شغل كشاورزى روى آورند. & $\Delta$ \\
\hline$-r$ & $-1 / F$ & به نظلر من يك كشاورز خوب كشاورزى است كه همه درآملد خود را از كشاورزى تأمين مى كند. & m \\
\hline$-r$ & $-\mathrm{V} / \Delta \mathrm{V}^{*}$ & يك كشاورز خوب بايد محصولات متنوعى در مزرعهاش كشت كند. & o \\
\hline$-r$ & $-1 / \Delta V^{*}$ & يى كشاورز نبايد به دولت وابسته باشد (هثلأ براى وام و كمى و غيره) بايد خودش روى باي خودش بايستد. & r. \\
\hline
\end{tabular}

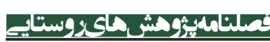

جدول A. آرايههاى عاملى و امتيازات عاملى استاندارد (Z)

\begin{tabular}{|c|c|c|c|}
\hline عاملي & 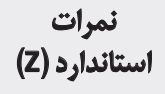 & مويلهاي موافقت & شمويه \\
\hline$r$ & $V(A)^{*}$ & يك كشاورز خوب بايد هحصولات مثنوعى نر مزرعهاش كشت كثل. & ro \\
\hline$r$ & V/\&" & به نظار من دولت بايد كود و سموم شيميايى را به وفور و با قيمت ارزان در خدمت كشاورزان قرار دهد. & rq \\
\hline$r$ & $V / g^{*}$ & 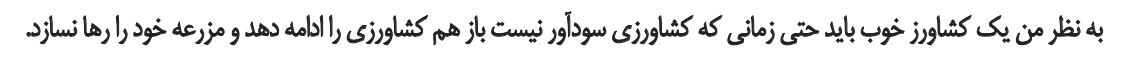 & $A$ \\
\hline$r$ & V/ev* & يك كشاورز نبايد به دولت وابسته باشد (مثلاً براى وام و كمى و غيره) بايد خودش روى ياى خودش بايستلد & r. \\
\hline r & V/F* & من دوست دارم وسعت مزرعه را افزايش و كارم را كسترش دهمه & u \\
\hline$r$ & V/T9* & كشاوز خوب كشاوزيست كه تا حد ممكن سعى كثلد مزرعلهاش را كسترش دهد. & f. \\
\hline$r$ & $V / I v^{*}$ & مهمترين هدف هن در كشاورزى برآورده كردن نيازهاي مردم كشورم و ثامين رفاه آثهاست. & r. \\
\hline 1 & .NE* & به نظر من در كشاورزى بايد از نيروى كار انسانى بسيار كم استفاده كرد و تا جايى كه مىشود از ادوات و ابيزار كشاورزى بهره برد. & $f$ \\
\hline 1 & $+N \Delta^{*}$ & به نظر من يك كشاورز بايد به خاطر حفظ محيط زيست توليد خود را كاهش دهل. & 19 \\
\hline 1 & $\cdot / M *^{*}$ & كشاوززان نبايد به خاطر تخريب آب يا خاك مورد سؤال قرار كيرند. & rr \\
\hline 1 & $\cdot / \Delta A^{*}$ & به نظر هن دولت بايد حد معينى براى استفاده از سهم وكود را تعيين كند. & re \\
\hline 1 &.$/ 4 \cdot$ & من دوست دارم فرزئدائم هم به شغل كشاورزى روى آورند. & $\Delta$ \\
\hline . & $\cdot / \mu *$ & به نظلر من يك كشاوزز بايد سعى كند روشهاى جديد كثاورزى را زودتر از اينكه ديكران به كار كيرند، به كار كيرد. & if \\
\hline • & $\bullet / \varphi^{*}$ & يك كشاوزز خوب كشاورزى است كه همه درآمد خود را از كشاورزى تأمين مى كثل. & rr \\
\hline$\cdot$ & / $/ *$ & دولت بايد قوائين محكمه و سختى در مورد استفاده از منابع آبى وخاكى براى كشاورزى بكذارد. & il \\
\hline
\end{tabular}




\begin{tabular}{|c|c|c|c|}
\hline عامليز & 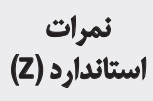 & كّويههاى مخالف & شوماره \\
\hline - & $-+/ m$ & به نظر خودم من يك كشاوزم ثأ كاركر، كاسب ثاجر يا هر جيز ديكرى. & ri \\
\hline-1 &.$- / 4 \nabla^{*}$ & من به شعل كشاوزىى بسيار وابسته نيستم و اكر شغل مناسبترى ييدا كنه، فوراً كشاورزى را رها مي كنم. & rq \\
\hline-1 & $-* / 4 * *$ & به نظر من يك كشاورز خوبه جديلترين تكنولورىىهاى كشاورزى را براى حداكثر سود اسثفاده مي كند. & $\checkmark$ \\
\hline-1 & $-\cdot / 4 r$ & كشاورز كسى است كه فقط در زمينه كشاورزى مهارت داشته باشد. & $\pi$ \\
\hline-1 & $-+18 *^{*}$ & كشاورزى شغل مخصوص روستا است و براى اين كار بايد روستايى باشد و تجربه داشته باشد. & 11 \\
\hline-1 &.$- / 9 f^{*}$ & به نظر من كشاورز خوب كشاورزى است كه با روشهاى كذشته و قديمى كشاورزى كند. & 9 \\
\hline-1 & $-1 / \cdot e^{\prime}$ & كسى كه بتواند بلون استفاده از كود و سمه شيميايي توليد كند، كشاوزز واقعى است. & r \\
\hline-1 & $-1 / 1 r^{*}$ & وظيفه اصلى كشاورزان بايد توليد غذاي سالمه باثلد، ارزائى خيلى مهم ئيست. & ro \\
\hline$-r$ & $-1 / 1 \%$ & كشاوزان واقعى نبايد كار ديكرى در خارج از مزرعه داشته باشنل. & 8 \\
\hline$-r$ & $-1 / 4 \varphi^{*}$ & كشاوز خوب فردى است كه محصولات و ارقام جديدى را كشت نمايلد. & r \\
\hline$-r$ & $-1 / 48 *$ & يك كشاوز خوب هحصولى را توليد هى كند كه بيشترين قيمت رادر بازار داشته باشد. & r \\
\hline$-r$ & $-1 / \Delta F^{*}$ & مهمترين هدف من در كشاورزى حداكثر سازى دراهد و كسب سود اقتصادى است. & iv \\
\hline$-r$ & $-1 / 8$. & به نظظر كسى كه خود را يك تاجر يا كاسب هي دائد نمى تواند يك كشاورز باشد. & iv \\
\hline$-r$ & $-1 / 8 \mathbb{F}^{\prime}$ & كشاورزان بايد هميجون كارمندان دولتي ديده شوند و به شدت بوسيله دولت حمايت شوند. & re \\
\hline$-r$ & $-1 / 8 A^{*}$ & وظيفه كشاورزان ايجاد محيطى فرح بخش، جذاب و توريستى براى جامعه است. & mi \\
\hline
\end{tabular}

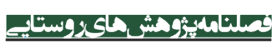

جدول ج. آرايههاى عاملى و امتيازات عاملى استاندارد (Z)

\begin{tabular}{|c|c|c|c|}
\hline عاملي & 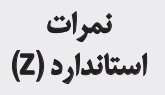 & كويلهاى موافث & كويه \\
\hline r & $V / A)^{*}$ & وظيفه اصلى كشاورزان بايد توليد غذاى سالم باشد، ارزانى خيلى مهم نيست. & ro \\
\hline r & I Me & كشاورزى شغل مخصوص مناطق روستايي است و فرد براى اين كار بايد روستايى باشد و تجربه اين كار را داشته باشد. & 11 \\
\hline r & $\mid / 8 I^{*}$ & من ترجيح مى دهم كاركر استخدلام نكنهم و همه كارها را خودم انجام دهام. & ru \\
\hline r & $1 / 4+$ & به نظر هن وظيفه اصلى كشاورزان برآورده كردن نيازهاى أنسانهاي فعلى است نه مواظبت از منابع براى نسلهاى آينذه. & 10 \\
\hline r & $1 / 4$. & به نظرم كسى كه خود را يك تاجر يا كاسب مي دائد نمىثوائد يك كشاورز باشد. & iv \\
\hline 1 & $1 / 19$ & كشاورز خوب فردى است كه محصولات و ارقام جديدى راكشت نمايد. & r \\
\hline 1 & $\cdot W^{*}$ & وظيفه كشاوززان ايجاد محيطى فرح بخش، جذاب و توريستى براى جامعه است. & er \\
\hline 1 & .199 & كسى كه بلون استفاده از كود و سم شيميايى توليد كند، كشاورز واقعى است. & r \\
\hline 1 &.$/ 49^{*}$ & من به شغل كشاورزى بسيار وابسته نيستم و اكر شغل مناسبترى ييدا كنم، قوراً كشاورزى را رها مى كنم. & rq \\
\hline 1 &.$/ 2$ & 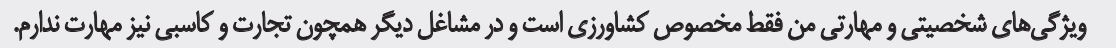 & $m$ \\
\hline
\end{tabular}




\begin{tabular}{|c|c|c|c|}
\hline عاملياز & 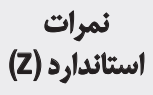 & 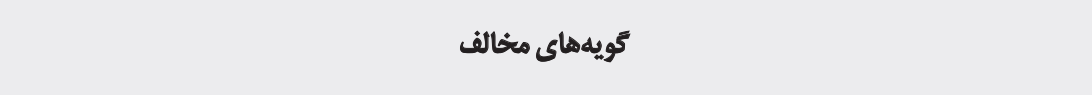 & كويماره \\
\hline+ & $-+110^{*}$ & ههمثرين هدف من در كشاورزى حلاكثر سازى درامد و كسب سود اقتصادى است. & iv \\
\hline - &.$- / I^{*}$ & به نظر من يك كشاورز بايد سعى كند روشهاي جليد كشاورزى را زودتر از اينكه ديكران به كار كيرنلة به كار كيرد. & If \\
\hline$\cdot$ & $-.10 A^{*}$ & من قصل دارم در آينده علاوه بر كشاوزي به مشاغل ديكرى ئيز بيردازم. & 18 \\
\hline-1 & $-+M i^{*}$ & كشاورزان نبايد به خاطر تخريب آب يا خاك مورد سوال قرار كيرثلد. & m \\
\hline-1 & $-M^{*}$ & من دوست دارم فرزندانم هم به شغل كشاوري روى آورند. & $\Delta$ \\
\hline-1 & 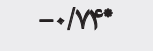 & به نظلر من يك كشاورز خوب بايد حتى زمانى كه كشاورزى سودآور نيست باز هم كشاورزى را ادامه لهلد و مزرعه خود را رها نسازد. & A \\
\hline-1 & $-+(\Lambda)^{*}$ & يك كشاورز نبايد به دولت وابسته باشد (مثلاً براى وام و كمك و غيره) بايد خودش روى يايى خودش بايستد. & $r \cdot$ \\
\hline-1 &.$- / u^{*}$ & يك كشاورز خوب بايد محصولات متنوعى در مزرعلاش كشت كند. & ro \\
\hline-1 & $-1 / / 4$ & يك كشاوز خوب كشاورزى است كه كل درآمد خود را از كشاورزى ثأمين كثلد. & M \\
\hline$-r$ & $-1 / M e^{2 *}$ & به نظظر من دولت بايد كود و سموم شيميايع را به وفور و با قيمت ارزان در خدمت كشاورزان قرار دهد. & rq \\
\hline$-r$ & $-\mid / M^{*}$ & 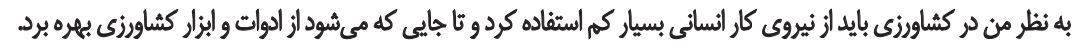 & r \\
\hline$-r$ & $-1 / \omega^{*}$ & من هي توائم هوفقيت شغل كشاورزيم را از طريق بازاريابى و ارتباط با مشتريان بهتر كنم. & ir \\
\hline$-r$ & $-1 / 79$ & من مي توائم محصولات خود را به طور مستقيم در بازار توزيع كنم. & r \\
\hline$-r$ & $-1 /\left.\Delta\right|^{*}$ & من دوست دارم وسعت مزرعه را افزايش و كارم را كسترش دهم. & $M$ \\
\hline
\end{tabular}

\section{然}

هويت كارآفرينى در بين كشاورزان مشاهده شد، به طور يقين

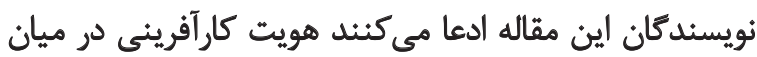

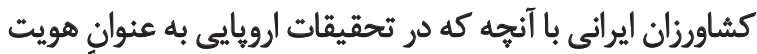

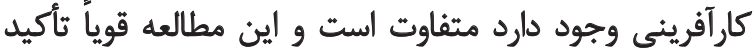

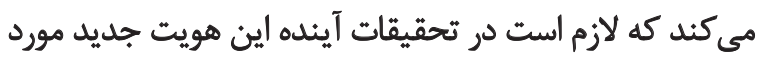

$$
\text { بررسى و تحليل قرار كيرد. }
$$

\section{بحث و نتيجهانَيرى}

در اين يُروهش بررسى هويت كشاورزان از آن جهت دنبال شده

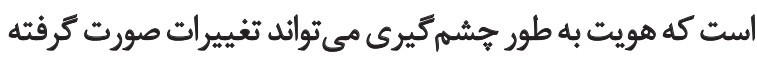

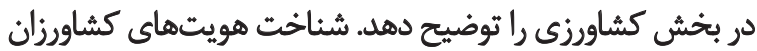

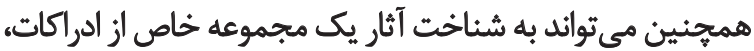

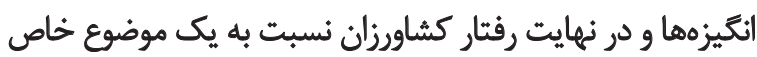

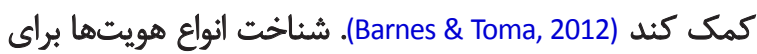

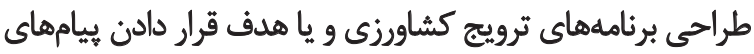

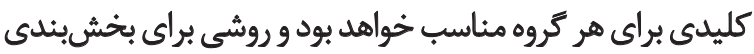

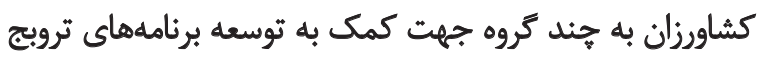

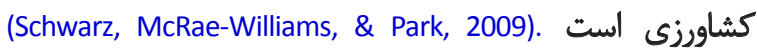

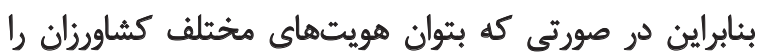

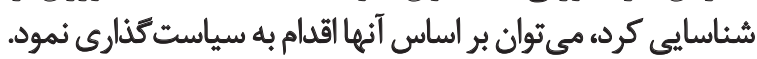

مخالف (1-) هستند. همجنين افراد اين گروه درمورد كويههاى

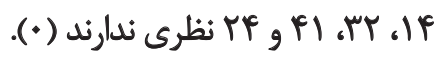

$$
\text { ويرّكى هاى هويث نوع سه: سنتى }
$$

همان كونه كه جدول شماره 9 نشان مي دهد، كشاورزان در اين

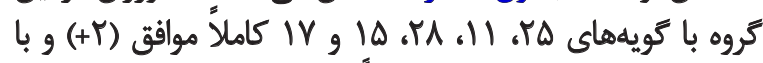
كويههاى

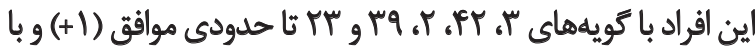

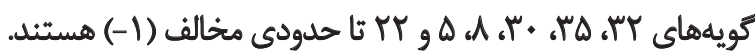

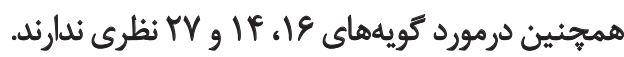

تطبيق نتايج اين مطالعه با مطالعات قبلى تا حدوديى دشوار

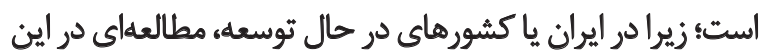

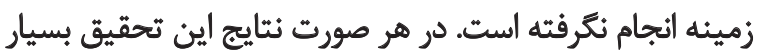

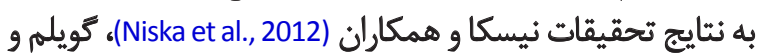

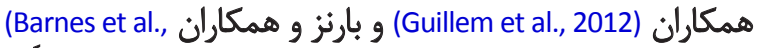

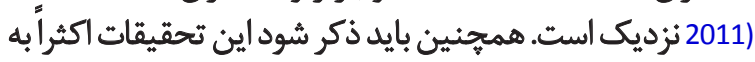

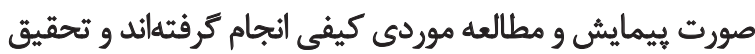

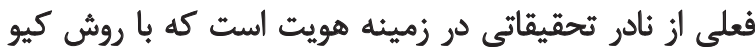

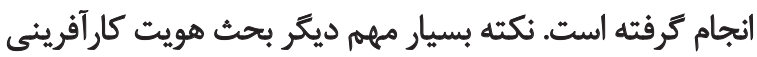

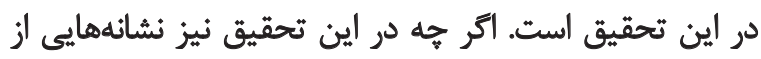


هراكه جشاير و همكاران (Cheshire, Meurk, \& Woods 2013)بيان

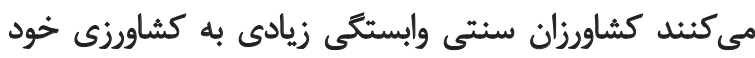
دارند و اين در حالى است كه كشاورزان عضو اين اين دسته بئن بيان

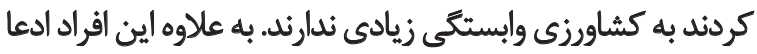

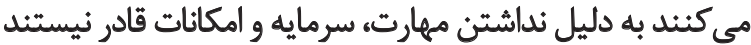

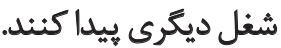

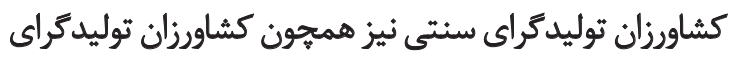

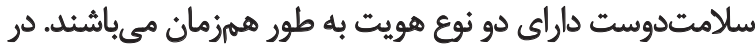

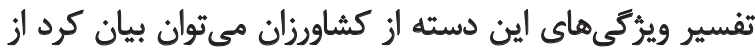

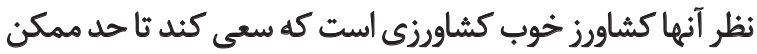

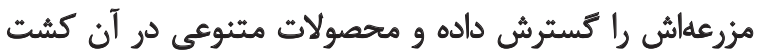

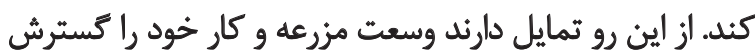

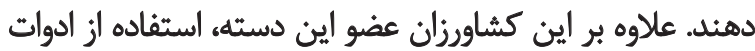

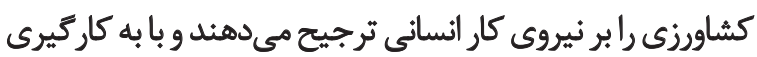

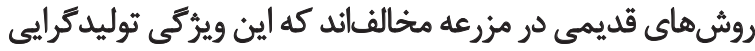
آنها را نشان مي قدهد (Wilson, 2001).

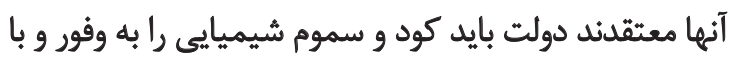

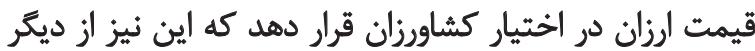

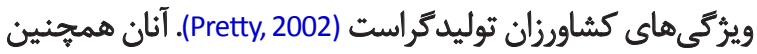

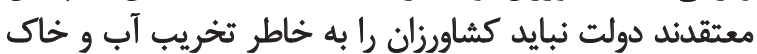

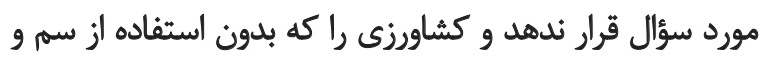

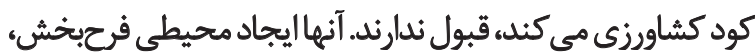

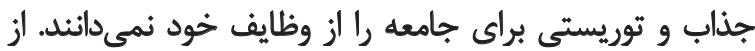

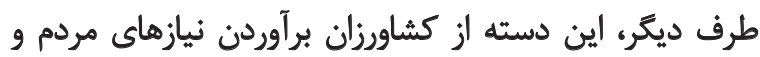

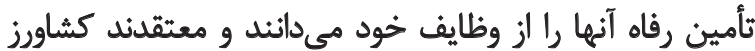

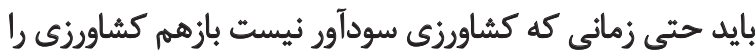

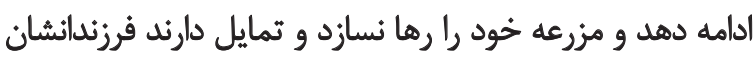

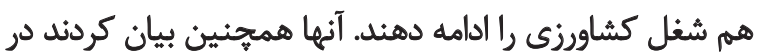

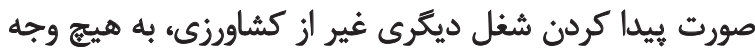

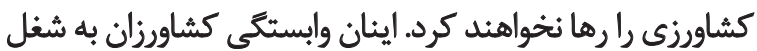

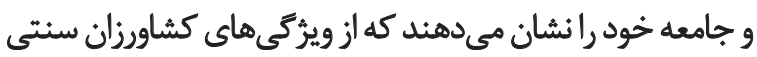
است (Cheshire et al., 2013).

كشاورزان عضو اين دسته همجنين بيان كردند يك كشاوري

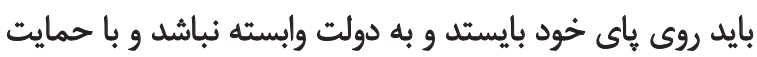

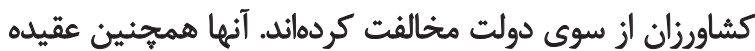

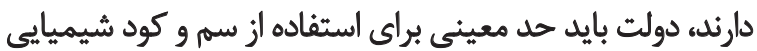

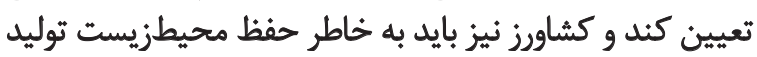

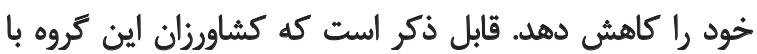

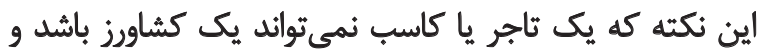
كشاورزى شغل مخصوص مناطق روستايى است، مخالف انداند. آنهابا اين مطلب كه كشاورز نبايد در خارج از مزرعه شغل دئل ديكرى داشتئه

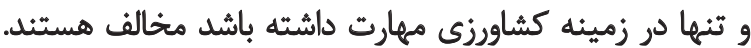
علاوه بر اين، با كشت محصولات جديد در مزيل مزرعه مخالفاند.
بر اساس نتايج يثروهش، سه نوع هويت در ميان كشاورزان

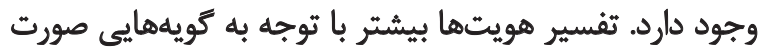

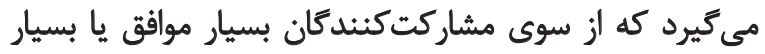

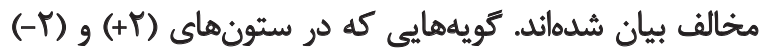

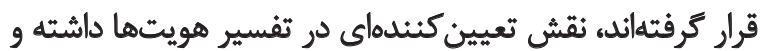

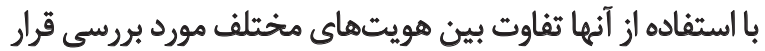

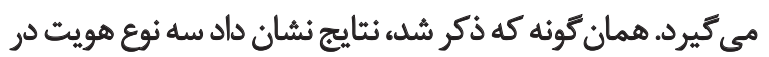

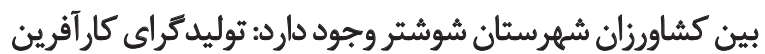

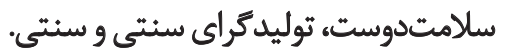
كشاورزان توليدكراى كارآرين سلامتدوست، كشاورزانى

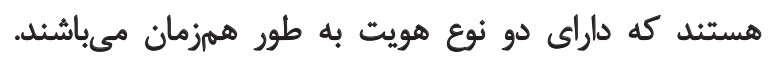

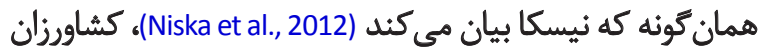

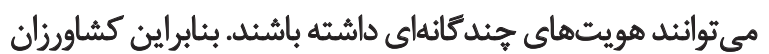

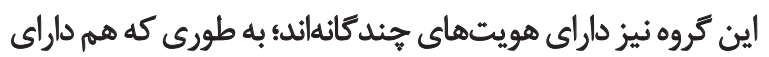

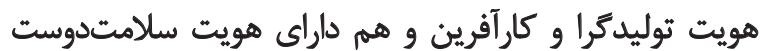

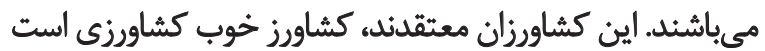

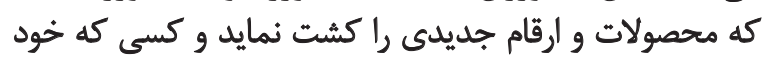

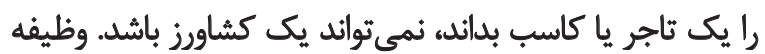

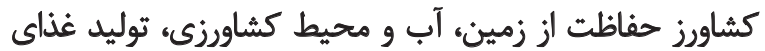

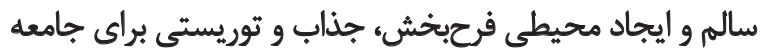

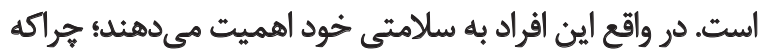

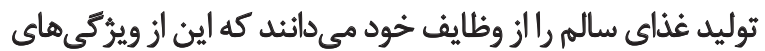

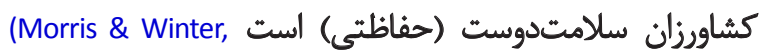

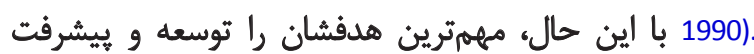

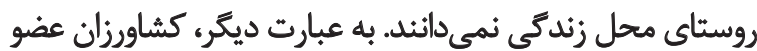

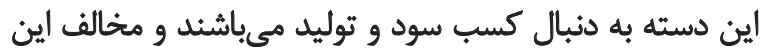

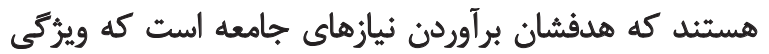
توليدكرا بودن آنها را نشان مي دهد (Wilson, 2001).

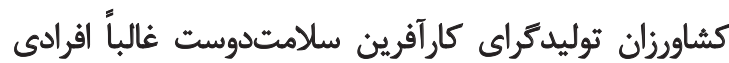

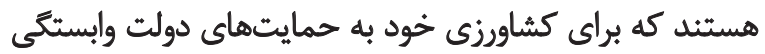

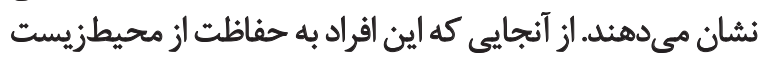

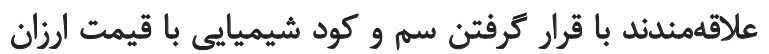

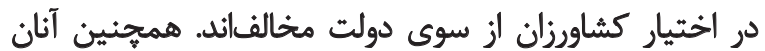

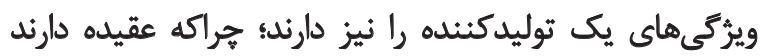

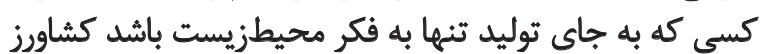

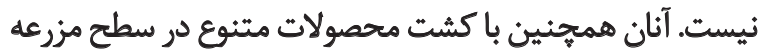

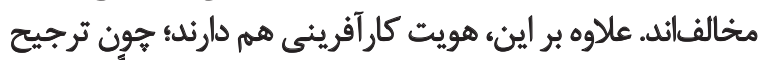

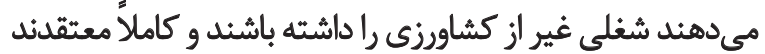

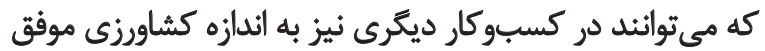

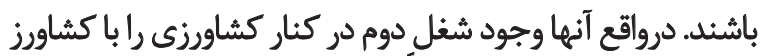

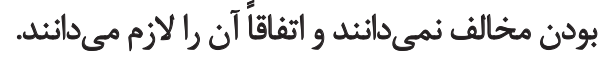

مي توان اظهار داشت كشاورزان اين تروه وابستگى زيادى به

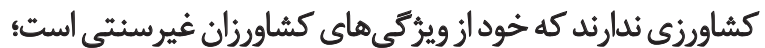


كردند. همجنين شناسايى انواع هويتها باعث مى شود هدف قرار

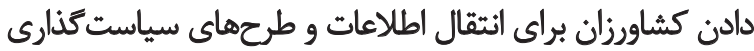
هزينه-اثربخشى بيشترى داشته باشند.

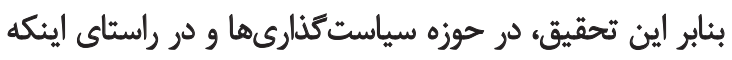

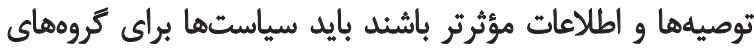

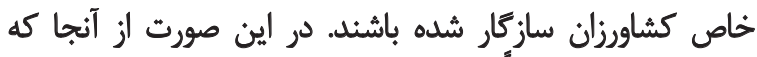

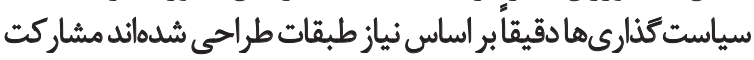

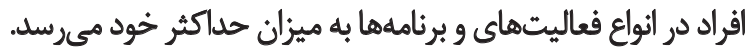

$$
\text { تشكر وقدودانى }
$$

بدينوسيله از ياسخ كويان محترم تحقيق تشكر و قدردانى

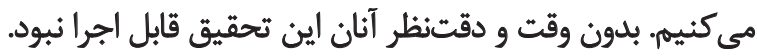

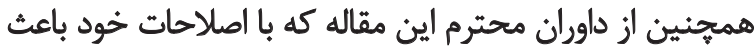

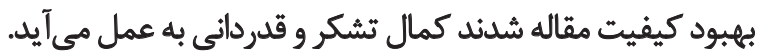
اين مقاله حامى مالى نداشته است.
كشاورزان دسته سوم وظيفه اصلى خود را ايجاد محيطي

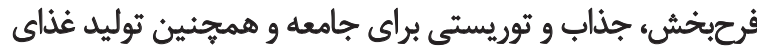

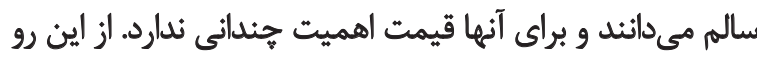

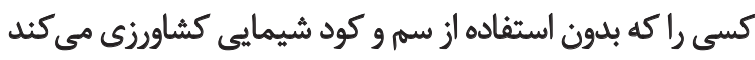

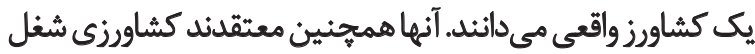

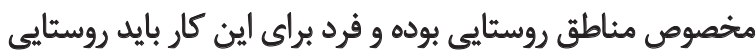

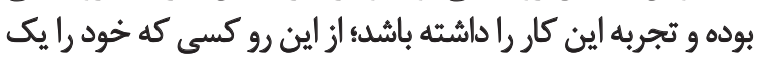

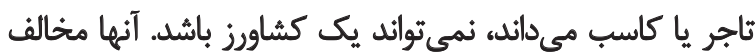

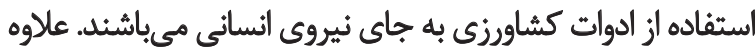

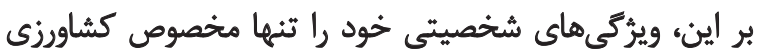

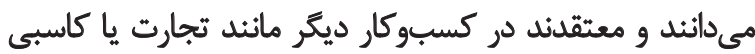

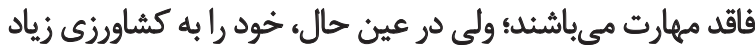

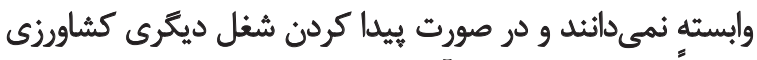

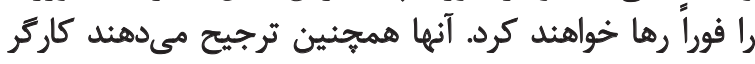

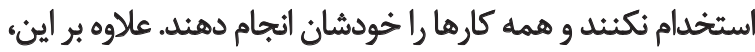

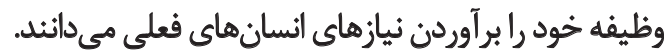

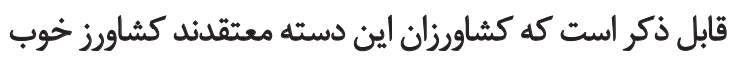

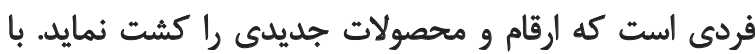

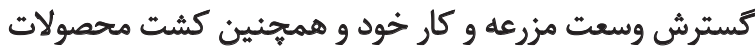

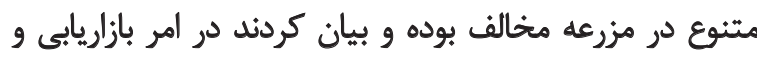

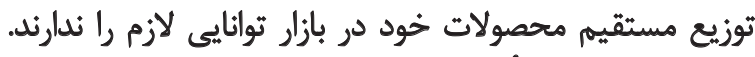

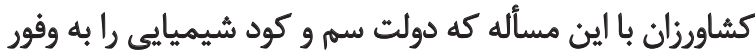

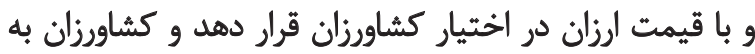

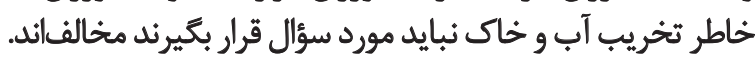

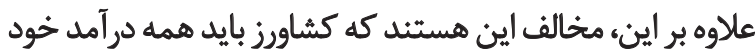

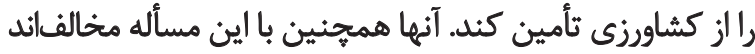

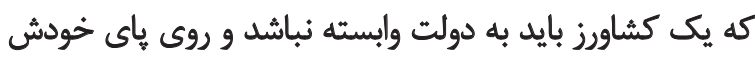

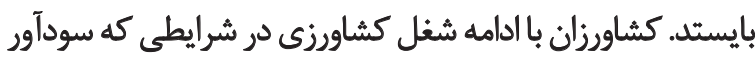

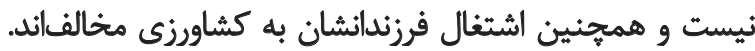

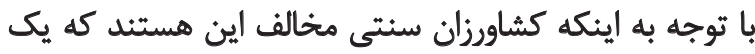

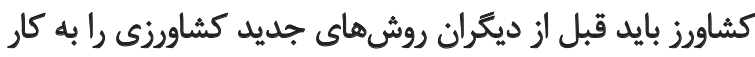

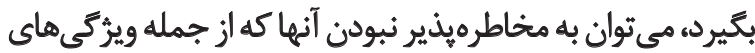

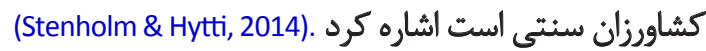

علاوه بر اينه آنان هدف اصلى خود را برآوردن نيازهاي افراد

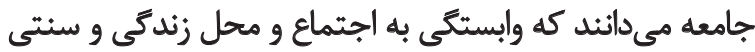

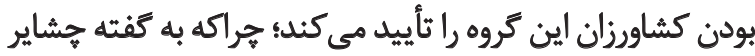

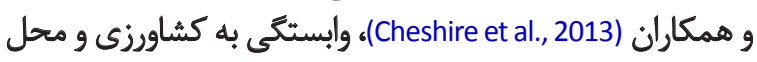

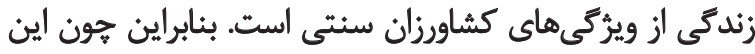

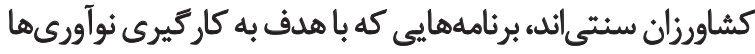

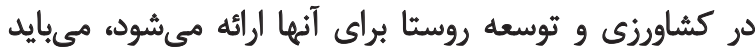

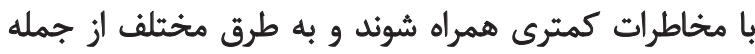

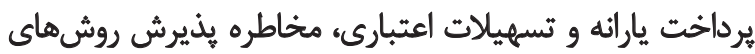

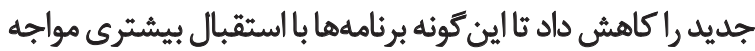




\section{References}

Ahmadian, M., \& Eslami, R., (2014). [Exploring attitudes toward Relationship between government and nation in Iran: A Q-methodology study (Persian)]. Quartery Journal of Macro and Streategic Policies. 1(4), 1-35.

Akhtar-Danesh, N., Baumann, A., \& Cordingley, L. (2008). Q-methodology in nursing research a promising method for the study of subjectivity. Western Journal of Nursing Research, 30(6), 759-773. doi: $10.1177 / 0193945907312979$

Alibaygi, A., \& GhambarAli, R. (2014). Exploring attitudes towards land consolidation impacts in Kermanshah Province: An application of Q-methodology. Iranian Agricultural Extension and Education Journal. 10(1), 75-88.

Amini Varaki, S., Modiri, M., Shamsayi Zafarghandi, F., \& Ghanbari Nasab, A. (2014). [Perspectives of the city's vulnerability to environmental hazards and its effective components by using the Q-Method (Persian)]. Emergency Management. 3(1), 5-18.

Azadi, H., Khosravipour., B., \& Yazdanpanah., M. (2015). [ Determinations of farmers' intention toward establishing mixed crop livestock system in Kohdasht District (Persian)]. Iranian Agricultural Extension and Education Journal. 10(2), 17-29.

Barnes, A. P., \& Toma, L. (2011). A typology of dairy farmer perceptions towards climate change. Climatic Change, 112(2), 507-522. doi: $10.1007 /$ s10584-011-0226-2

Barnes, A. P., Willock, J., Toma, L., \& Hall, C. (2011). Utilising a farmer typology to understand farmer behaviour towards water quality management: Nitrate vulnerable zones in Scotland. Journal of Environmental Planning and Management, 54(4), 477-494. doi: 10.1080/09640568.2010.515880

Brandth, B. (2002). Gender identity in European family farming: A literature review. Sociologia Ruralis, 42(3), 181-200. doi: 10.1111/1467-9523.00210.

Bryant, L. (1999). The detraditionalization of occupational identities in farming in South Australia. Sociologia Ruralis, 39(2), 236-261. doi: 10.1111/1467-9523.00104

Burton, R. J. (2004). Seeing through the 'good farmer's' eyes: Towards developing an understanding of the social symbolic value of 'productivist' behaviour. Sociologia Ruralis, 44(2), 195-215. doi: 10.1111/j.1467-9523.2004.00270.x

Burton, R. J. F. (2004). Reconceptualising the "behavioural approach" in agricultural studies: A socio-psychological perspective. Journal of Rural Studies, 20(3), 359-371. doi: 10.1016/j.jrurstud.2003.12.001

Burton, R. J. F., \& Wilson, G. A. (2006). Injecting social psychology theory into conceptualisations of agricultural agency: Towards a post-productivist farmer self-identity? Journal of Rural Studies, 22(1), 95-115. doi: 10.1016/j.jrurstud.2005.07.004

Burton, R. J. F., Kuczera, C., \& Schwarz, G. (2008) Exploring farmers' cultural resistance to voluntary agri-environmental schemes. Sociologia Ruralis, 48(1), 16-37. doi: 10.1111/j.1467-9523.2008.00452.x

Carter, S. (2001). Multiple business ownership in the farm sectorDifferentiating monoactive, diversified and portfolio enterprises. International Journal of Entrepreneurial Behavior \& Research, 7(2), 43-59. doi: $10.1108 / 13552550110695552$

Cheshire, L., Meurk, C., \& Woods, M. (2013). Decoupling farm, farming and place: Recombinant attachments of globally engaged family farmers. Journal of Rural Studies, 30, 64-74. doi: 10.1016/j. jrurstud.2012.11.005

Cook, A. J., Kerr, G. N., \& Moore, K. (2002). Attitudes and intentions towards purchasing GM food. Journal of Economic Psychology, 23(5), 557-572. doi: 10.1016/s0167-4870(02)00117-4

Cuppen, E., Breukers, S., Hisschemöller, M., \& Bergsma, E. (2010). Q methodology to select participants for a stakeholder dialogue on energy options from biomass in the Netherlands. Ecological Economics, 69(3), 579-591. doi: 10.1016/j.ecolecon.2009.09.005

Dessein, J., \& Nevens, F. (2007). 'I'm sad to be glad'. An analysis of farmers' pride in Flanders. Sociologia Ruralis 47(3), 273-292. doi: 10.1111/j.1467-9523.2007.00437.x

Forouzani, M., Karami, E., Zamani, G. H., \& Moghaddam, K. R (2013). Agricultural water poverty: Using Q-methodology to understand stakeholders' perceptions. Journal of Arid Environments, 97, 190-204. doi: 10.1016/j.jaridenv.2013.07.003

Gonzalez, J. J., \& Benito, C. G. (2001). Profession and identity. The case of family farming in Spain. Sociologia Ruralis, 41(3), 343-357. doi: 10.1111/1467-9523.00187

Guillem, E. E., Barnes, A. P., Rounsevell, M. D. A., \& Renwick, A. (2012). Refining perception-based farmer typologies with the analysis of past census data. Journal of Environmental Management, 110, 226-235. doi: 10.1016/j.jenvman.2012.06.020.

Hogg, M. A., Terry, D. J., \& White, K. M. (1995). A tale of two theories: A critical comparison of identity theory with social identity theory. Social Psychology Quarterly, 58(4), 255. doi:10.2307/2787127

James, H. S., \& Hendrickson, M. K. (2010). Are farmers of the middle distinctively "Good Stewards"? Evidence from the Missouri farm poll, 2006. Journal of Agricultural and Environmental Ethics, 23(6), 571-590. doi: 10.1007/s10806-009-9228-8

Khoshgouyanfard., A. (2006). [Q-methodology (Persian)]. Tehran: Islamic Republic of Iran Broadcasting

Klandermans, B., Sabucedo, J. M., Rodriguez, M., de Weerd, M. (2002). Identity processes in collective action participation: Farmers' identity and farmers' protest in the Netherlands and Spain. Political Psychology, 23(2), 235-251.

Lockie, S. (2006). Networks of agri-environmental action: Temporality, spatiality and identity in agricultural environments. Sociologia Ruralis, 46(1), 22-39. doi: 10.1111/j.1467-9523.2006.00400.x

Mather, A. S., Hill, G., \& Nijnik, M. (2006). Post-productivism and rural land use: Cul de sac or challenge for theorization? Journal of Rural Studies, 22(4), 441-455. doi: 10.1016/j.jrurstud.2006.01.004

McElwee, G. (2008). In search of Montsalvatch: Making sense of interviewing farmers. Tamara Journal. 7(7), 139-153.

McGuire, J., Morton, L. W., \& Cast, A. D. (2012). Reconstructing the good farmer identity: Shifts in farmer identities and farm management practices to improve water quality. Agriculture and $\mathrm{Hu}$ man Values, 30(1), 57-69. doi: 10.1007/s10460-012-9381-y

Monfared, N., Yazdanpanah, M., \& Tavakoli, K. (2015). Why do they continue to use pesticides? The case of tomato growers in Boushehr province in Southern Iran. Journal of Agricultural Science and Technology, 17(3), 577-588

Morris, C., \& Winter, M. (1999). Integrated farming systems: The third way for European agriculture? Land Use Policy, 16(4), 193205. doi: 10.1016/s0264-8377(99)00020-4 
Laoire, C. N. (2002). Young farmers, masculinities and change in rural Ireland. Irish Geography, 35(1), 16-27. doi: $10.1080 / 00750770209555790$

Mohammadi Tamari, Z., Ahmadvand, M., \& Ghasemi, S. (2014). [Rice farmers' attitudes towards change in cropping pattern from rice to citrus production: A Q-method approach (Persian)]. Iranian Agricultural Extension and Education Journal. 9(2), 89-106.

Moradian, F. (2011). [Q-methodology (Persian)]. Social Sciences, 37, 96-101.

Niska, M., Vesala, H. T., \& Vesala, K. M. (2012). Peasantry and entrepreneurship as frames for farming: Reflections on farmers' values and agricultural policy discourses. Sociologia Ruralis, 52(4), 453469. doi: 10.1111/j.1467-9523.2012.00572.x

Pelling, E. L., \& White, K. M. (2009). The theory of planned behavior applied to young people's use of social networking websites. CyberPsychology \& Behavior, 12(6), 755-759. doi: 10.1089/ cpb.2009.0109

Podedworna, H. (1998). Modern farmers: New class of the polish rural society, Working paper No. 49. Liverpool: University of Liverpool.

Poya, A., \& Loghmani, H. (2013). [Q methodology research strategy (place, application, method, limitations and its opposition with R methodology) (Persian)]. Tose'e-ye Sazmani-ye Polis, 10(2), 87-106.

Pretty, J. N. (2002). Agriculture: Reconnecting people, land and nature. London: Earthscan.

Previte, J., Pini, B., \& Haslam-McKenzie, F. (2007). Q methodology and rural research. Sociologia Ruralis, 47(2), 135-147. doi: 10.1111/j.1467-9523.2007.00433.x

Rezaei-Moghaddam, K., Karami, E., \& Gibson, J. (2005). Conceptualizing sustainable agriculture: Iran as an illustrative case. Journal of Sustainable Agriculture, 27(3), 25-56. doi: 10.1300/j064v27n03_04

Schwarz, I., McRae-Williams, P., \& Park, D. (2009). Identifying and utilising a farmer typology for targeted practice change programs: A case study of changing water supply in the Wimmera Mallee. Extension Farming Systems Journal, 5(1), 33-42.

Sharpley, R., \& Vass, A. (2006). Tourism, farming and diversification: An attitudinal study. Tourism Management, 27(5), 1040-52. doi: 10.1016/j.tourman.2005.10.025

Shoshtari, M., \& Omani. A. (2012). [Factors influencing the adoption behavior of summer crop farmers in Shoushtar Township regarding integrated pest management (Persian)]. Journal of Agricultural Extension and Education Research, 5(2), 45-56

Shucksmith, M., \& Herrmann, V. (2002). Future changes in British agriculture: Projecting divergent farm household behaviour. Journal of Agricultural Economics, 53(1), 37-50. doi: 10.1111/j.14779552.2002.tb00004.x

Stenholm, P., \& Hytti, U. (2014). In search of legitimacy under institutional pressures: A case study of producer and entrepreneur farmer identities. Journal of Rural Studies, 35, 133-142. doi: 10.1016/j.jurstud.2014.05.001

Stets, J. E., Burke, P. J. (2003). A sociological approach to self and identity. In M. R. Leary, \& J. P. Tangney, (Eds.), Handbook of Self and Identity (pp. 128-152). New York: Guildford Press.

Stryker, S. (1968). Identity salience and role performance: The importance of symbolic inter action theory for family research. Journal of Marriage and the Family 30(4), 558-564. doi: 10.2307/349494
Stryker, S. (1980). Symbolic interactionism: A social structural version. Michigan: Benjamin/Cummings Publishing Company.

Stryker, S., \& Burke, P. (2000). The past, present, and future of an identity theory. Social Psychology Quarterly, 63(4), 284-297.

Terry, D. J., Hogg, M. A., \& White, K. M. (1999). The theory of planned behaviour: Self-identity, social identity and group norms. British Journal of Social Psychology, 38(3), 225-244. doi 10.1348/014466699164149

Valenta, A. L., \& Wigger, U. (1997). Q-methodology: Definition and application in health care informatics. Journal of the American Medical Informatics Association, 4(6), 501-510. doi: 10.1136/ jamia.1997.0040501

Vesala, H. T., \& Vesala, K. M. (2010). Entrepreneurs and producers: Identities of Finnish farmers in 2001 and 2006. Journal of Rural Studies, 26(1), 21-30. doi: 10.1016/j.jurstud.2009.06.001

Mikko Vesala, K., Peura, J., \& McElwee, G. (2007). The split entrepreneurial identity of the farmer. Journal of Small Business and Enterprise Development, 14(1), 48-63. doi: 10.1108/14626000710727881

Vesala, K. M., \& Rantanen, T. (1999). [Mere talk is not enough. Social psychological conditions for constructing an entrepreneurial identity among farmers (Finnish)]. Jyväskylä: Yliopistopaino

Walford, N. (2003). Productivism is allegedly dead, long live productivism. Evidence of continued productivist attitudes and decision-making in South-East England. Journal of Rural Studies, 19(4), 491-502. doi: 10.1016/s0743-0167(03)00030-5

Watts, S., \& Stenner, P. (2005). Doing Q methodology: Theory, method and interpretation. Qualitative Research in Psychology, 2(1), 67-91. doi: 10.1191/1478088705qp022oa

Webler, T., Danielson, S., \& Tuler, S. (2009). Using Q method to reveal social perspectives in environmental research. Greenfield: Social and Environmental Research Institute.

Wilson, G. A. (2001). From productivism to post-productivism ... and back again? Exploring the (un)changed natural and mental landscapes of European agriculture. Transactions of the Institute of British Geographers, 26(1), 77-102. doi: 10.1111/1475-5661.00007

Wilson, G. A. (2008). From "weak" to "strong" multifunctionality: Conceptualising farm-level multifunctional transitional pathways. Journal of Rural Studies, 24(3), 367-383. doi: 10.1016/j. jrurstud.2007.12.010

Wilson, G. A., \& Burton, R. J. F. (2015). “Neo-productivist" agriculture: Spatio-temporal versus structuralist perspectives. Journal of Rural Studies, 38, 52-64. doi: 10.1016/j.jrurstud.2015.02.003

Yakova, I. (2006). Czech Republic, 'Europe' and its farmers: How is agricultural interest intermediation affected by accession to the EU. European Political Economy Review, 3(2), 112-142.

Yeganeh, Gh. (2013). [Shavadan; Element of the sustainable architecture in the City of Shushtar (Persian)]. Paper presented at The $8^{\text {th }}$ National Conference on Architecture, Urban Planning and Sustainable Development of Vernacular Architecture With a Focus on the Sustainable City, Mashhad, Iran, 26 December, 2013.

Yazdanpanah, M., Feyzabad, F. R., Forouzani, M., Mohammadzadeh, S., \& Burton, R. J. F. (2015). Predicting farmers' water conservation goals and behavior in Iran: A test of social cognitive theory. Land Use Policy, 47, 401-407. doi: 10.1016/j.landusepol.2015.04.022 
Yazdanpanah, M., Hayati, D., Zamani, G. H., Karbalaee, F., \& Hochrainer-Stigler, S. (2013). Water management from tradition to second modernity: An analysis of the water crisis in Iran. Environment, Development and Sustainability, 15(6), 1605-1621. doi: 10.1007/s10668-013-9452-2.

Zarei, Z., Modhej, A. \& Lorzadeh, SH. (2011). [Effect of integrated weed management (chemical and mechanical) on grain yield of corn hybrid S.C 700 under Shoushtar conditions (Persian)]. Iranian Journal of Field Crops Research, 12(1), 73-79. 